\title{
Survival effect of radial artery usage in addition to bilateral internal thoracic arterial grafting: A meta-analysis
}

\author{
Francesco Formica, MD, ${ }^{\mathrm{a}}$ Francesco Maestri, MD, ${ }^{\mathrm{a}}$ Stefano D'Alessandro, MD, FECTS, ${ }^{\mathrm{b}}$ \\ Michele Di Mauro, MD, PhD, MSc, ${ }^{\mathrm{c}, \mathrm{d}}$ Gurmeet Singh, MD, ${ }^{\mathrm{e}, \mathrm{f}}$ Alan Gallingani, MD, and \\ Francesco Nicolini, MD, $\mathrm{PhD}^{\mathrm{a}}$
}

\section{ABSTRACT}

Objective: Little evidence shows whether the radial artery (RA) as third arterial graft provides superior outcomes compared with the use of the bilateral internal thoracic artery (BITA) and saphenous vein (SV) graft in patients undergoing coronary artery bypass grafting. A meta-analysis of propensity score-matched observational studies that compared the long-term outcomes of coronary artery bypass grafting with the use of BITA and the RA (BITA + RA) versus BITA and SV (BITA + SV) was performed.

Methods: Electronic databases from January 2000 to November 2020 were screened. Studies that reported long-term mortality were analyzed. The primary outcome was long-term overall mortality. A secondary end point was in-hospital/ 30-day mortality. Pooled hazard ratio with $95 \%$ confidence interval $(\mathrm{Cl})$ were calculated for survival and time-to-event analysis according to a random effect model. Differences were expressed as odds ratio with $95 \% \mathrm{Cl}$ for in-hospital/30-day mortality.

Results: Six propensity score-matched studies that reported on 2500 matched patients (BITA + RA: 1250; BITA + SV: 1250) were identified for comparison. The use of BITA + RA was not statistically associated with early mortality (odds ratio, 0.90; $95 \% \mathrm{Cl}, 0.36-2.28 ; P=.83$ ). The mean follow-up time ranged from 7.5 to 12 years. The pooled analysis of long-term survival revealed a significant difference between the 2 groups favoring BITA + RA treatment (hazard ratio, $0.71 ; 95 \% \mathrm{Cl}, 0.50-0.91$; $P=.031)$. The survival rate for BITA + RA versus BITA + SV at 5, 10, and 15 years were: $96.2 \%$ versus $94.8 \%, 88.9 \%$ versus $87.4 \%$, and $83 \%$ versus $77.9 \%$, respectively (log rank test, $P=.02$ ).

Conclusions: In patients with coronary artery bypass grafting, BITA + RA usage is not associated with higher rates of operative risk and is associated with superior long-term overall survival. (J Thorac Cardiovasc Surg 2021;

:1-10)

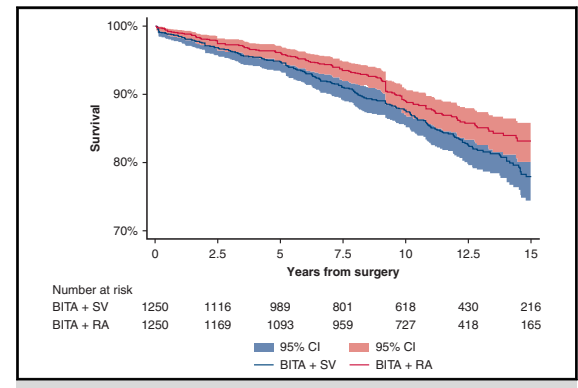

The BITA + RA is associated with better long-term survival compared with BITA + SV.

CENTRAL MESSAGE

In patients with coronary artery bypass grafting, BITA + RA usage is not associated with higher operative risk and is associated with superior long-term overall survival.

\section{PERSPECTIVE}

Coronary surgery using the RA and BITA is likely the best option because of longer-term patency of arterial conduits compared with the SV. However, routine use of this approach is reported in approximately $4 \%$ to $12 \%$ of patients, globally. In this meta-analysis we observed that BITA + RA is associated with a significant longer-term survival compared with BITA + SV.

See Commentary on page $\mathrm{XXX}$.

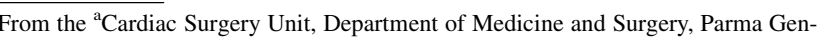
eral Hospital, University of Parma, Parma, Italy; ${ }^{b}$ Cardiac Surgery Unit, Vito Fazzi Hospital, Lecce, Italy; ${ }^{\mathrm{c}}$ Invasive Cardiology and Heart Failure Unit, Medicine Department, "Pierangeli" Hospital, Pescara, Italy; 'Cardio-Thoracic Surgery Unit, Heart and Vascular Centre, Maastricht University, Maastricht, The Netherlands; ${ }^{\mathrm{e}}$ Medical Centre (MUMC), Cardiovascular Research Institute Maastricht (CARIM), Maastricht, The Netherlands; and ${ }^{\mathrm{f}}$ Division of Cardiac Surgery and Department of Critical Care Medicine, Mazankowski Alberta Heart Institute, University of Alberta, Edmonton, Alberta, Canada.
Received for publication March 9, 2021; revisions received June 8, 2021; accepted for publication June 30, 2021.

Address for reprints: Francesco Formica, MD, UOC Cardiochirurgia, Azienda Ospedaliera Universitaria di Parma, Via A. Gramsci, 14, 43126 Parma, Italy (E-mail francescoformica.hs@gmail.com or francesco.formica@unipr.it).

J Thorac Cardiovasc Surg 2021; $\mathbf{\square}: 1-10$

0022-5223/ $\$ 36.00$

Copyright $(C) 2021$ by The American Association for Thoracic Surgery

https://doi.org/10.1016/j.jtcvs.2021.06.062 


$\begin{aligned} & \text { Abbreviations and Acronyms } \\ & \text { BITA }=\text { bilateral internal thoracic artery } \\ & \text { BITA }+ \text { RA }=\text { bilateral internal thoracic artery and } \\ & \text { the radial artery } \\ & \text { BITA }+ \text { SV }= \text { bilateral internal thoracic artery and } \\ & \text { the saphenous vein } \\ & \text { CABG }=\text { coronary artery bypass grafting } \\ & \text { CI }=\text { confidence interval } \\ & \text { HR }=\text { hazard ratio } \\ & \text { LITA }=\text { left internal thoracic artery } \\ & \text { MAG }=\text { multiple arterial grafts } \\ & \text { OR }=\text { odds ratio } \\ & \text { PSM }=\text { propensity score-matched } \\ & \text { RA }=\text { radial artery } \\ & \text { RAPCO }=\text { Radial Artery Patency and Clinical } \\ & \text { Outcome } \\ & \text { RITA }=\text { right internal thoracic artery } \\ & \text { rGEA }=\text { right gastroepiploic artery } \\ & \text { SITA }=\text { single internal thoracic artery } \\ & \text { SV }=\text { saphenous vein } \\ & \text { TAR }=\text { total arterial revascularization }\end{aligned}$

$\checkmark$ Video clip is available online.

The most recent European guidelines on myocardial revascularization recommend coronary artery bypass grafting (CABG) for patients with significant triple vessel coronary artery disease. ${ }^{1}$ In this context, the use of the bilateral internal thoracic artery (BITA) is still debated. The Arterial Revascularization Trial showed similar results between using the single internal thoracic artery (SITA) compared with the BITA at 10 years. $^{2}$ In this trial, several reasons might explain the lack of evidence of benefit of BITA over SITA. Approximately $22 \%$ of patients assigned to the SITA group received a radial artery (RA) as a second arterial graft, which is proven to have a superior patency compared with the saphenous vein (SV). Moreover, there was an unexpected crossover rate with $14 \%$ of patients assigned to the BITA group who received a SITA graft. Furthermore, the high rate of guideline-based medical treatment in this randomized trial might have narrowed differences in long-term clinical results between the 2 groups. A number of observational studies and meta-analyses consistently show superiority of the BITA strategy and multiple arterial grafts (MAG) over the SITA plus SV graft $^{3-7}$ and percutaneous coronary intervention. ${ }^{8,9}$ However, there are still conflicting long-term results reported for patients who received BITA and RA compared with patients who received BITA and $\mathrm{SV} .^{10-13}$ In 2 recent meta-analyses ${ }^{14,15}$ better long-term survival of patients with 3 arterial grafts (BITA with either RA [BITA + RA] or right gastroepiploic artery [rGEA]) compared with BITA with the SV (BITA + SV) was observed.

To the best of our knowledge, no meta-analysis on the long-term outcomes of BITA + RA compared with BITA + SV has been published to date. To overcome this limitation, we aimed to present the best available evidence on the issue with a meta-analysis of propensity score-matched (PSM) retrospective observational studies that compared the long-term outcomes of CABG in patients who received BITA + RA compared with $\mathrm{BITA}+\mathrm{SV}$.

\section{METHODS}

\section{Search Strategy and Eligibility}

This systematic review and meta-analysis were conducted according to the Preferred Reporting Items for Systematic Reviews and Meta-Analyses (PRISMA) guidelines. ${ }^{16}$ The study protocol was registered and published online in the International Prospective Register of Systematic Reviews (PROSPERO ID: CRD42021225834).

A systematic search was performed from January 1, 2000 to November 30, 2020 in 3 electronic databases: PubMed, SCOPUS and EMBASE. Search terms used alone or in combination included "bilateral internal thoracic artery," "bilateral internal mammary artery," "radial artery," "arterial conduits," "long-term results," "coronary artery bypass grafting," and "total arterial revascularization."

This systematic review was on the basis of the Population, Intervention, Comparison, Outcomes, Studies (PICOS) format:

Population: patients with isolated 3-vessel coronary artery disease;

Intervention: isolated CABG with BITA + RA;

Comparison: CABG with BITA $+\mathrm{SV}$;

Outcomes: long-term survival; and

Studies: PSM studies.

The following inclusion criteria were used to select relevant studies: (1) patients underwent isolated CABG, (2) patients received BITA with either the RA or SV, (3) long-term survival comparing patients with BITA + RA with patients with BITA + SV, (4) PSM as the only strategy to control for confounding. Studies written in languages other than English were excluded, as were editorials, letters, case reports, meta-analyses, and review articles.

Three authors (F.M., S.D., A.G.) independently scanned and reviewed titles and abstracts to identify articles that met the inclusion criteria. In cases of disagreement a senior author (F.F.) made the decision of whether to include or exclude the study.

\section{Data Collection and Extraction}

Data extraction was performed by 3 (F.M., S.D., A.G.) reviewers and reported in a standard table sheet (Microsoft Office Excel 2016, Microsoft, Redmond, Wash). GetData Graph Digitizer version 2.26.0.20 (http:// getdata-graph-digitizer.com) was used to digitalize the graph of KaplanMeier curves and to finally extract the hazard ratio (HR) and the corresponding $95 \%$ confidence interval (CI), if these were not cited in the study. ${ }^{17,18}$ Median and interquartile range were converted into mean and standard deviation following the recommendations of Luo and colleagues. ${ }^{19}$ Each study included in the meta-analysis was identified by study design, study period, first authors, affiliation, and year of publication. The following data on patient preoperative factors were collected: age, sex (female), hypertension, diabetes, hyperlipidaemia, chronic obstructive coronary disease, peripheral vascular disease, left ventricular ejection fraction, previous myocardial infarction, and left main disease. 


\section{End Points}

The primary end point was long-term overall mortality. For this end point, $\mathrm{HR}$ and the corresponding $95 \% \mathrm{CI}$ were extracted, or were reported, if the values were expressed in the studies included in the meta-analysis. The secondary end point was early mortality, which was defined as mortality occurring within 30 days or during the index hospitalization.

\section{Statistical Analysis}

The pooled effect size with odds ratio (OR) and $95 \%$ CI using the Mantzel-Haenszel method was calculated for 30-day or in-hospital mortality. Pooled HR with $95 \%$ CI were calculated for survival and time-to-event analysis according to the random effect. Forest plots were created to represent the primary outcome and to determine the effect size. The $\chi^{2}$ test and $I^{2}$ test were performed to assess the statistical heterogeneity, defined as low for $I^{2}$ ranging from $0 \%$ to $25 \%$, moderate for $I^{2}$ ranging from $26 \%$ to $50 \%$, and high for $I^{2}$ greater than $50 \%{ }^{20}$

Funnel plots were created to represent the publication bias graphically using the trim and fill method, and analysed using the Egger ${ }^{21}$ and Begg and Mazumdar tests. ${ }^{22}$ Sensitivity analysis was applied to assess the influence of a single study on the overall effect of BITA + RA treatment on the main outcome by sequentially removing 1 study, following the leave-oneout method. ${ }^{23}$ Meta-regression analysis was performed to determine the effects of preidentified factors. The factors used in meta-regression analysis were selected from the following variables: female sex, diabetes, hypertension, nonelective surgery, and previous myocardial infarction.

For survival analysis, we reconstructed the database of each article using the method described by Wei and colleagues. ${ }^{24}$ All data were merged into 1 global database and life tables, survival curves, and HRs were calculated. The log rank test was used to assess differences between the 2 groups. A stratified Cox proportional hazard model was used to calculate the HR of BITA + SV versus BITA + RA treatment. The HR was calculated by reconstructing the original database and performing a univariate Cox model. This method was tested by graphing the obtained survival curves and visually comparing them with the original curves. When the original publication reported the $\mathrm{HR}$, the new calculated HR was compared with the original HR and was used for the analysis.

Continuous variables were reported as mean \pm standard deviation. Categorical variables were reported as percentages. All $P$ values were 2-tailed. All of the statistical analyses were computed with ProMeta3 software (http://idostatistics.com/prometa3/), Stata/MP version 16.1 (Stata Corp, College Station, Tex), and with Review Manager (RevMan5) version 5.3 (The Cochrane Collaboration, 2012, The Nordic Cochrane Centre, Copenhagen, Denmark).

\section{RESULTS}

\section{Study Selection and Literature Search}

A total of 523 titles and abstracts were identified, of which 22 full-text articles were considered relevant for the meta-analysis. After evaluating the full-text articles, 6 studies ${ }^{10-13,25,26}$ met eligibility criteria and were included in this meta-analysis. The PRISMA flow chart of the study selection process is shown in Figure 1.
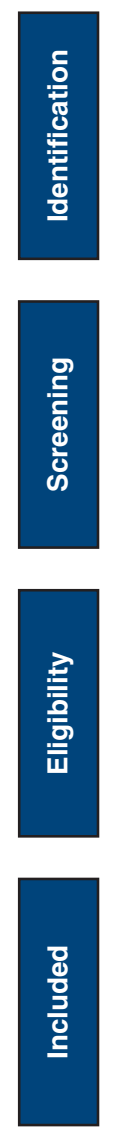

Additional records identified

through other sources database searching

$$
(n=523)
$$


Patients' characteristics and study typology are shown in Table 1. Graft configuration, location of the RA graft, and stenosis degree of the RA coronary target are reported in Table E1. Overall, the included studies reported on $2500 \mathrm{pa}-$ tients, with 1250 patients in each group. The NewcastleOttawa quality assessment scale for observational studies confirmed the level of quality of the selected articles (Table E2).

\section{Study Primary End Point: Long-Term Mortality}

All studies reported the long-term mortality comparison between BITA + RA and BITA + SV with a mean follow-up ranging from 7.5 to 12 years in the overall population. At the longest follow-up, survival ranged from $78.6 \%$ to $92 \%$ in the BITA + RA group and from $67 \%$ to $83 \%$ in the BITA + SV group. The longest follow-up was more than 22.5 years. ${ }^{12}$ The pooled analysis of longterm survival revealed a significant difference between the 2 groups favoring BITA + RA treatment (HR, 0.71; 95\% CI, 0.50-0.91; $P=.03$ ) with evidence of low heterogeneity $\left(I^{2}=17.04 \% ; T^{2}=0.01 ; P=.38\right.$; Figure $\left.2, A\right)$. Leave-oneout analysis did not indicate any significant effect on overall outcome with any one study being removed (Figure 2, $B$ ). Table 2 shows HRs described in the original reports and HRs calculated using the reconstructed database. In the 3 studies ${ }^{11-13}$ that reported HR, the new calculated HR was consistent. The pooled Kaplan-Meier is shown in Figure 3 . The log rank test was statistically significant favoring the BITA + RA treatment $(P=.02)$. The survival rate for BITA + RA versus BITA + SV at 5, 10, and 15 years were: $96.2 \%(95 \%$ CI, $94.9 \%-97.1 \%)$ versus $94.8 \%(95 \%$ CI, $93.3 \%-95.9 \%), 88.9 \% \quad(95 \%$ CI， $86.9 \%-90.7 \%)$ versus $87.4 \%(95 \% \mathrm{CI}, 85.1 \%-89.3 \%)$, and $83 \%(95 \%$ CI, $79.9 \%-85.6 \%$ ) versus $77.9 \%$ (95\% CI, $74.4 \%-81 \%$ ). This means a number needed to treat of 20.61 patients at 15 years follow-up. A smoothed hazard function according the type of treatment is shown in Figure E1. All reconstructed survival curves are shown in Figure E2 through E7. Funnel plot analysis did not reveal publication bias related to long-term survival (Egger's linear regression test: $P=.844$; Begg and Mazumdar test: $P=.573$; Figure E8).

Meta-regression analysis showed no effect of diabetes $(P=.776)$, female sex $(P=.745)$, hypertension $(P=.165)$, previous myocardial infarction $(P=.982)$, and nonelective surgery $(P=.900)$ with the primary end point, suggesting that the results were not influenced by any of these factors (Figures E9-E13). Unfortunately, there were not sufficient data to perform meta-regression to correct for patient age.

\section{Study Secondary End Point: Early Mortality}

Five studies (2318 patients) ${ }^{10-13,26}$ reported on the early mortality results between BITA + RA and BITA + SV groups; early mortality ranged between $0.4 \%$ to $1.1 \%$ in the overall population. Between the groups, early mortality ranged from $0.4 \%$ to $1.1 \%$ in the BITA + RA group and from $0.5 \%$ to $1.1 \%$ in the BITA $+\mathrm{SV}$ group. Pooled

TABLE 1. Risk factors of populations included in the analysis

\begin{tabular}{|c|c|c|c|c|c|c|}
\hline \multirow[b]{2}{*}{ Study } & \multicolumn{2}{|c|}{ Patient n } & \multicolumn{2}{|c|}{ Age, mean \pm SD or $n(\%)$} & \multicolumn{2}{|c|}{ Male sex, n (\%) } \\
\hline & $\overline{\text { BITA + RA }}$ & $\overline{\text { BITA }+ \text { SVG }}$ & BITA + RA & BITA + SVG & $\overline{\text { BITA + RA }}$ & BITA + SVG \\
\hline $\begin{array}{l}\text { Shi et al }^{10} \\
\text { Australia } \\
\text { Study period } 1977-2010\end{array}$ & 262 & 262 & $60 \pm 8.7$ & $60 \pm 9.2$ & $236(90)$ & $238(91)$ \\
\hline $\begin{array}{l}\text { Mohammadi et al }{ }^{11} \\
\text { Canada Study period } \\
\text { 1991-2013 }\end{array}$ & 249 & 249 & $56.1 \pm 8.9$ & $55.8 \pm 8.9$ & $225(90.3)$ & $221(88.7)$ \\
\hline $\begin{array}{l}\text { Benedetto et } \mathrm{al}^{12} \\
\text { UK } \\
\text { Study period } 1996-2015\end{array}$ & 275 & 275 & $\begin{array}{l}<60: 176(64) \\
\text { 60-69: } 70(25.5) \\
\text { 70-79: } 28(10.2) \\
>80: 1(0.4)\end{array}$ & $\begin{array}{l}<60: 181(65.8) \\
60-69: 78(28.4) 70-79: \\
12(4.4)>80: 4(1.5)\end{array}$ & $257(93.4)$ & $259(94.2)$ \\
\hline $\begin{array}{l}\text { Formica et } \mathrm{al}^{13} \\
\text { Italy } \\
\text { Study period } 1999-2017\end{array}$ & 190 & 190 & $60.7 \pm 6.7$ & $59.5 \pm 6.4$ & $165(86.8)$ & $167(87.9)$ \\
\hline $\begin{array}{l}\text { Grau et } \mathrm{al}^{25} \\
\text { US } \\
\text { Study period 2000-2013 }\end{array}$ & 183 & 183 & $57 \pm 10$ & $58 \pm 9$ & $169(92.3)$ & $171(93.4)$ \\
\hline $\begin{array}{l}\text { Yoshida et }^{26} \\
\text { Japan } \\
\text { Study period } 1997-2007\end{array}$ & 91 & 91 & $64.0 \pm 8.8$ & $64.7 \pm 9.7$ & $70(76.9)$ & $69(75.8)$ \\
\hline
\end{tabular}


TABLE 1. Continued

\begin{tabular}{|c|c|c|c|c|c|c|c|c|}
\hline \multicolumn{2}{|c|}{ Diabetes mellitus, n (\%) } & \multicolumn{2}{|c|}{ Hypertension, n (\%) } & \multicolumn{2}{|c|}{ Previous myocardial infarction, n (\%) } & \multicolumn{2}{|c|}{ Nonelective surgery, n (\%) } & \multirow{2}{*}{$\begin{array}{c}\text { Longest } \\
\text { follow-up, y }\end{array}$} \\
\hline$\overline{\text { BITA }+ \text { RA }}$ & BITA + SVG & BITA + RA & BITA + SVG & BITA + RA & BITA + SVG & BITA + RA & BITA + SVG & \\
\hline $34(13)$ & $34(13)$ & $130(50)$ & $132(50)$ & $114(44)$ & $114(44)$ & $42(16)$ & $41(16)$ & 15 \\
\hline $30(12.1)$ & $34(13.7)$ & $134(53.8)$ & $145(58.2)$ & $119(47.8)$ & $121(48.6)$ & $66(26.5)$ & $65(26.1)$ & 25 \\
\hline $18(6.54)$ & $15(5.4)$ & $171(62.18)$ & $177(64.3)$ & $149(54.2)$ & $151(54.1)$ & $112(40.7)$ & $110(40)$ & 17.3 \\
\hline $41(21.5)$ & $34(13.7)$ & $163(85.8)$ & $161(84.7)$ & $45(23.7)$ & $44(23.2)$ & $11(5.8)$ & $9(4.7)$ & 18.5 \\
\hline $11(6)$ & $10(5.5)$ & $125(68.3)$ & $125(68.3)$ & $74(40.4)$ & $73(39.9)$ & $97(53)$ & $100(54.6)$ & 14 \\
\hline $35(38.5)$ & 38 (41.8) & 49 (53.8) & 45 (49.5) & $30(30)$ & $30(33)$ & $7(7.7)$ & $8(8.8)$ & 12 \\
\hline
\end{tabular}

estimates effect sizes revealed no difference between the 2 groups (OR, $0.90 ; 95 \% \mathrm{CI}, 0.36-2.28 ; P=.83)$ with no evidence of heterogeneity $\left(I^{2}=0 \% ; P=.92\right.$; Figure 4$)$. Funnel plot analysis did not reveal publication bias (Egger linear regression test: $P=.694$; Begg and Mazumdar test: $P=.142$ ). Brief study methods and results are shown in Figure 5 and Video 1.

\section{DISCUSSION}

The left internal thoracic artery (LITA) and SV remain the most frequently used CABG operation. However, at 10 years the SVs have a reported occlusion rate of $50 \%$ to $60 \%{ }^{27,28}$ This is due to endothelial and media hyperplasia resulting in atherothrombosis, with a reduction of patency of the vein grafts. BITA is not always suitable, and use of a third arterial conduit, either RA or rGEA is required to achieve a total arterial revascularization (TAR) in 3-vessel coronary artery disease.

Patient age and the life expectancy at the time of surgery are paramount considerations in selecting the ideal myocardial revascularization strategy for 3-vessel coronary artery disease. In patients younger than 60 years old or with a life expectancy of at least 15 to 20 years, TAR is likely the best option because of improved longer-term patency of arterial conduits compared with SVs. ${ }^{29,30}$ Moreover, there is encouraging evidence of the long-term benefit of TAR and BITA usage in patients older than 70 years. ${ }^{31}$ Such results should be useful in guiding surgeons in the more extensive use of the TAR.

In a recent meta-analysis, Gaudino and colleagues analyzed 8 PSM observational studies, and compared the long-term outcomes of CABG with the use of 2-arterial versus 3-arterial grafts in a matched population of 10,287 patients. ${ }^{14}$ The use of a third arterial graft was associated with an increase of $24 \%$ survival benefit at a mean follow-up of 77.9 months, regardless of patient sex or diabetes mellitus. The authors concluded that TAR should be a cornerstone of up-to-date coronary artery surgery.

In a meta-analysis of PSM observational studies, the long-term survival of TAR versus non-TAR strategy was compared, and TAR with BITA versus TAR without BITA. $^{32}$ The TAR strategy showed a long-term survival benefit over non-TAR. Moreover, patients who received BITA had a grater survival benefit in terms of arterial graft patency, despite an increased risk of sternal wound infections compared with the TAR group without BITA.

In a recent meta-analysis Di Mauro and colleagues ${ }^{15}$ analyzed the long-term effect of a third arterial conduit on the right coronary artery system in addition to the BITA. A leave-one-out analysis, with the exclusion of 1 study, ${ }^{33}$ showed the use of an arterial conduit, either the RA or the rGEA, on the right coronary artery system, resulted in higher rates of long-term survival compared with use of the SV as third graft in addition to the BITA.

In the present meta-analysis we examined the effect of coronary myocardial revascularization with BITA + RA compared with BITA $+\mathrm{SV}$ at long-term follow-up. Overall analysis of the PSM studies showed a significant difference between the RA and SV usage, favoring the BITA + RA treatment. This initial observation was not influenced by the results of the leave-one-out analysis. One strength point 


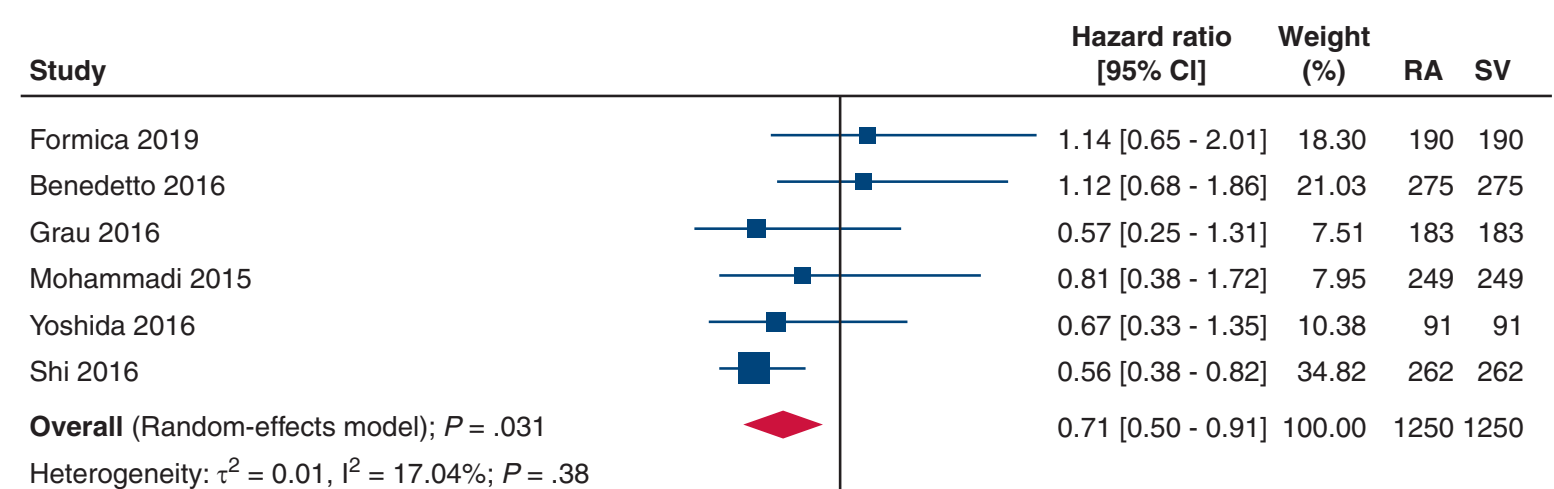

A

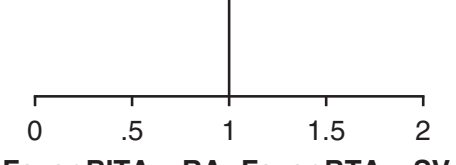

Favor BITA + RA Favor BTA + SV

\begin{tabular}{|c|c|c|c|c|}
\hline & ES & $95 \% \mathrm{Cl}$ & Sig. & $\mathbf{N}$ \\
\hline Benedetto 2016 & 0.74 & $0.58-0.93$ & 0.011 & 1950 \\
\hline Formica 2019 & 0.72 & $0.59-0.87$ & 0.001 & 2120 \\
\hline Grau 2016 & 0.78 & $0.66-0.93$ & 0.006 & 2134 \\
\hline Mohammadi 2015 & 0.76 & $0.63-0.92$ & 0.006 & 2002 \\
\hline Shi 2016 & 0.83 & $0.70-0.99$ & 0.037 & 1976 \\
\hline Yoshida 2016 & 0.77 & $0.64-0.93$ & 0.008 & 2318 \\
\hline
\end{tabular}

B

FIGURE 2. A, Forest plot for overall long-term survival. Coronary artery bypass graft (CABG) with bilateral internal thoracic artery and radial artery $(B I T A+R A)$ is associated with better survival compared with CABG with BITA and the saphenous vein $(B T A+S V) . I^{2}, 17.04 \%$ indicates low heterogeneity. B, Forest plot of the leave-one-out analysis of the effect of the use of the radial artery and the saphenous vein in addition to the bilateral internal thoracic arteries. $C I$, Confidence interval; ES, estimation size (hazard ratio); Sig, $P$ value.

of our study is related to the comparison of only 2 different grafts (either RA or SV) as a third conduit used in addition to the BITA, unlike the aforementioned meta-analysis in which the comparison was between any arterial graft and the SV.

The clinical benefit of the RA for complete arterial revascularization is recognized, but its use in clinical practice has lagged. In a meta-analysis of 1036 patients Gaudino and colleagues $^{34}$ reported a low incidence of cardiac events, myocardial infarction, repeat myocardial revascularization, and death from any causes. Furthermore, a higher rate of 5year patency in the RA graft compared with the SV graft was also reported by analyzing data from randomized trials, such as the Radial Artery Patency Study (RAPS) trial and Radial Artery Versus Saphenous Vein Patency (RSVP) trial. Both trials have reported superior angiographic graft patency of the RA compared with the SV at 5 years postoperatively whereas data from the Radial Artery Patency and Clinical Outcome (RAPCO) trial showed no differences in terms of 5-year patency between the RA and the SV. ${ }^{35}$ These conflicting data might explain the low usage of the $\mathrm{RA}$ as an arterial conduit in CABG, even though recent data from large retrospective studies ${ }^{8,9}$ have shown that MAG improves late survival. Nevertheless, routine use of BITA is applied in only approximately $4 \%$ of coronary patients in Canada, ${ }^{36} 7 \%$ to $10 \%$ in the United States, ${ }^{37,38}$ and in $12 \%$ in Europe ${ }^{39}$ with a slightly higher percentage in Japan $(22.7 \%) .^{40}$ The reluctance of many surgeons to use MAG remains a major obstacle to increasing the use of this strategy. The problem is multifactorial and complex. The development of a TAR program lead by an experienced surgeon in TAR, with the goal of gradually training 
TABLE 2. Hazard ratio of risk of death of BITA + SVG versus BITA + RA during the follow-up

\begin{tabular}{|c|c|c|}
\hline Authors & $\frac{\text { Original report }}{\text { HR }(95 \% \text { CI })}$ & $\frac{\text { Reconstructed database }}{\text { HR }(95 \% \mathrm{CI})}$ \\
\hline $\begin{array}{l}\text { Shi et al }^{10} \\
\text { Australia } \\
\text { Study period } 1977-2010\end{array}$ & - & $0.56(0.38-0.82)$ \\
\hline $\begin{array}{l}\text { Mohammadi et } \text { al }^{11} \\
\text { Canada } \\
\text { Study period 1991-2013 }\end{array}$ & $0.9(0.4-2.0)$ & $0.81(0.38-1.72)$ \\
\hline $\begin{array}{l}\text { Benedetto et } \mathrm{al}^{12} \\
\text { UK } \\
\text { Study period 1996-2015 }\end{array}$ & $1.16(0.71-1.91)$ & $1.12(0.68-1.86)$ \\
\hline $\begin{array}{l}\text { Formica et } \text { al }^{13} \\
\text { Italy } \\
\text { Study period } 1999-2017\end{array}$ & $1.07(0.63-1.82)$ & $1.14(0.65-2.01)$ \\
\hline 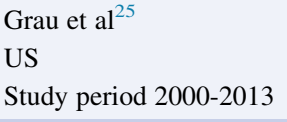 & - & $0.57(0.25-1.31)$ \\
\hline 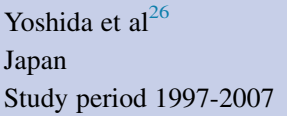 & - & $0.67(0.33-1.35)$ \\
\hline
\end{tabular}

HR, Hazard ratio; $C I$, confidence interval; $U K$, United Kingdom; US, United States.

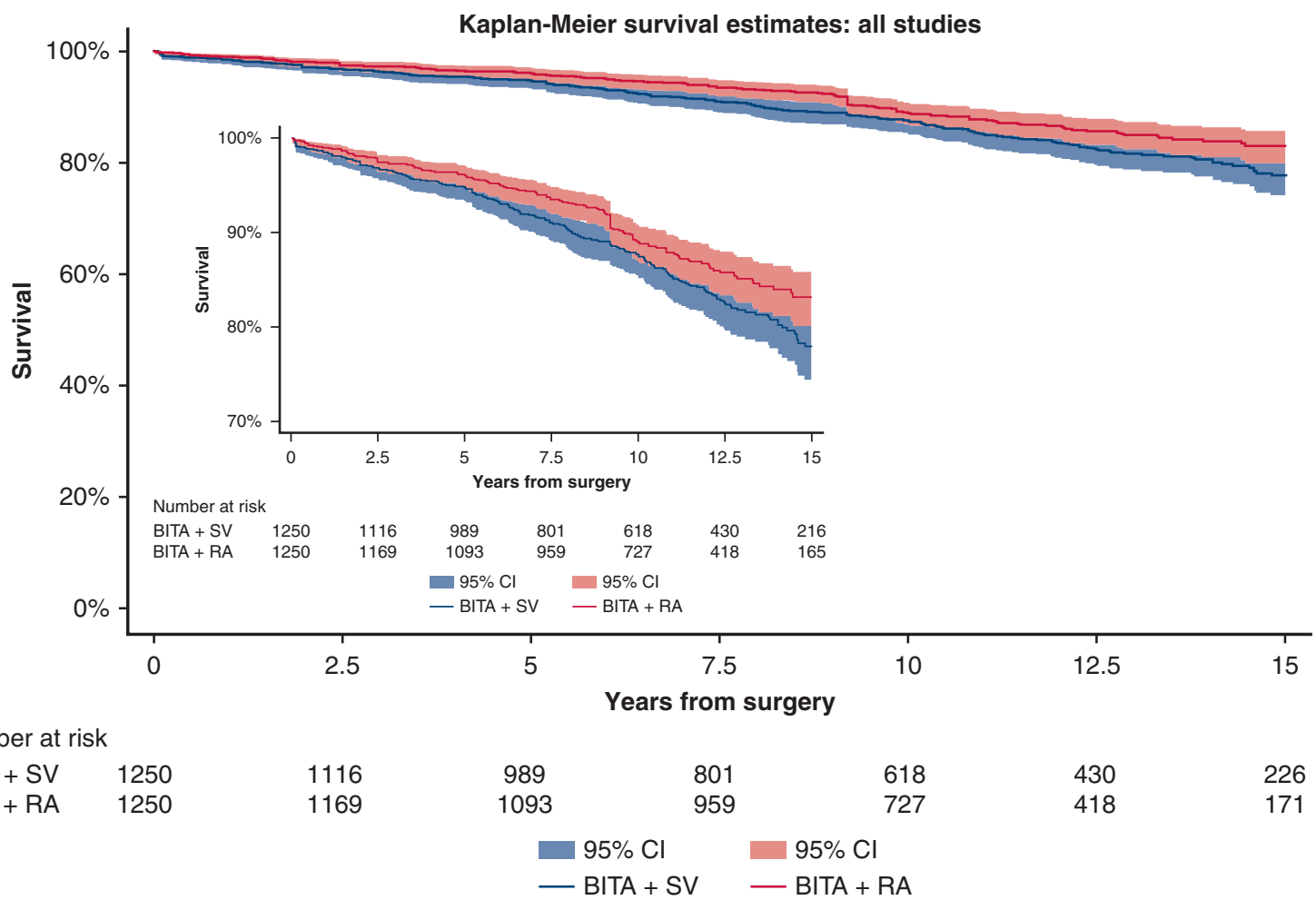

FIGURE 3. Kaplan-Meier survival curves of the global sample. The bilateral internal thoracic artery and radial artery $(B I T A+R A)$ group is associated with better long-term survival compared with the bilateral internal thoracic artery and saphenous vein $(B I T A+S V)$ group. All databases were pooled into 1 global database. The log rank test was statistically significant favoring the BITA + RA group $(P=.02)$. The inset shows a magnification of the survival curve with the Y-axis values (survival) ranging from $70 \%$ to $100 \%$. CI, Confidence interval. 


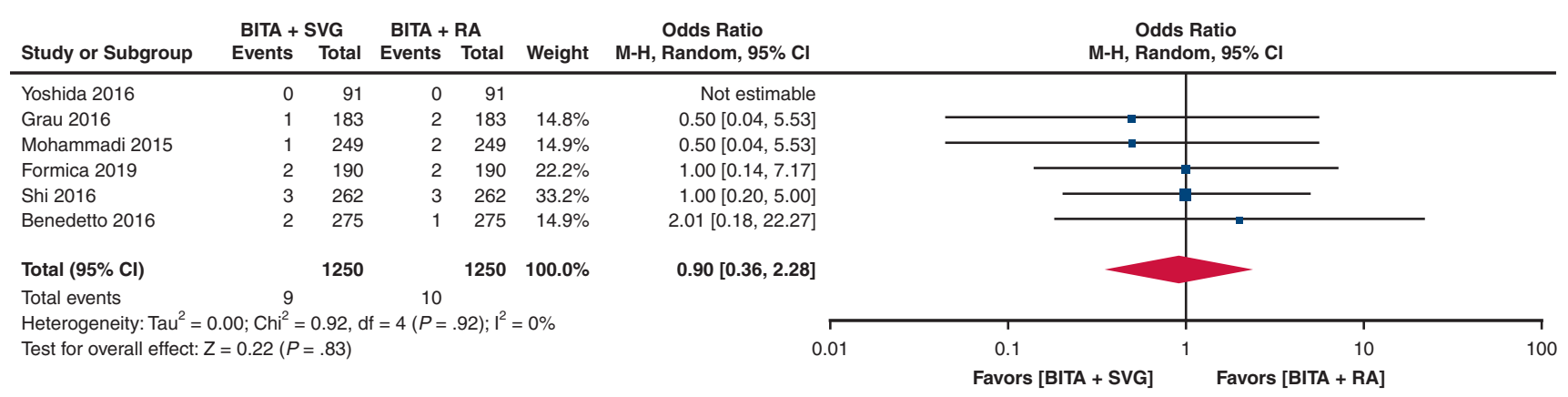

FIGURE 4. Forest plot for early mortality. No statistical differences were observed between the BITA + RA and BITA + SVG groups. BITA + SVG, Bilateral internal thoracic artery and saphenous vein; $B I T A+R A$, bilateral internal thoracic artery and radial artery; $C I, 95 \%$ confidence interval.

surgeons in conduit harvesting, patient selection, and literature review, could be the key for increasing MAG usage. ${ }^{41}$

Recent data from the RAPCO trial ${ }^{30}$ showed better 10year angiographic results of the RA compared with the $\mathrm{SV}$, and showed an almost $60 \%$ reduction in the rate of RA graft failure compared with the SV (HR, 0.40; $95 \%$ CI, 0.15-1.00). This trial also showed a lower 10-year patency of free right internal thoracic artery (RITA) compared with the RA. However, free RITA was used as aortocoronary graft, which is an uncommon practice. It is noteworthy that the median age of patients who participated in that randomized trial was 73 years and the report of the first 5-year angiographic results failed to show any differences between the 2 grafts. ${ }^{35}$ A recent prospective study that included patients with a mean age of 60 years who received either MAG (BITA + RA with or without the

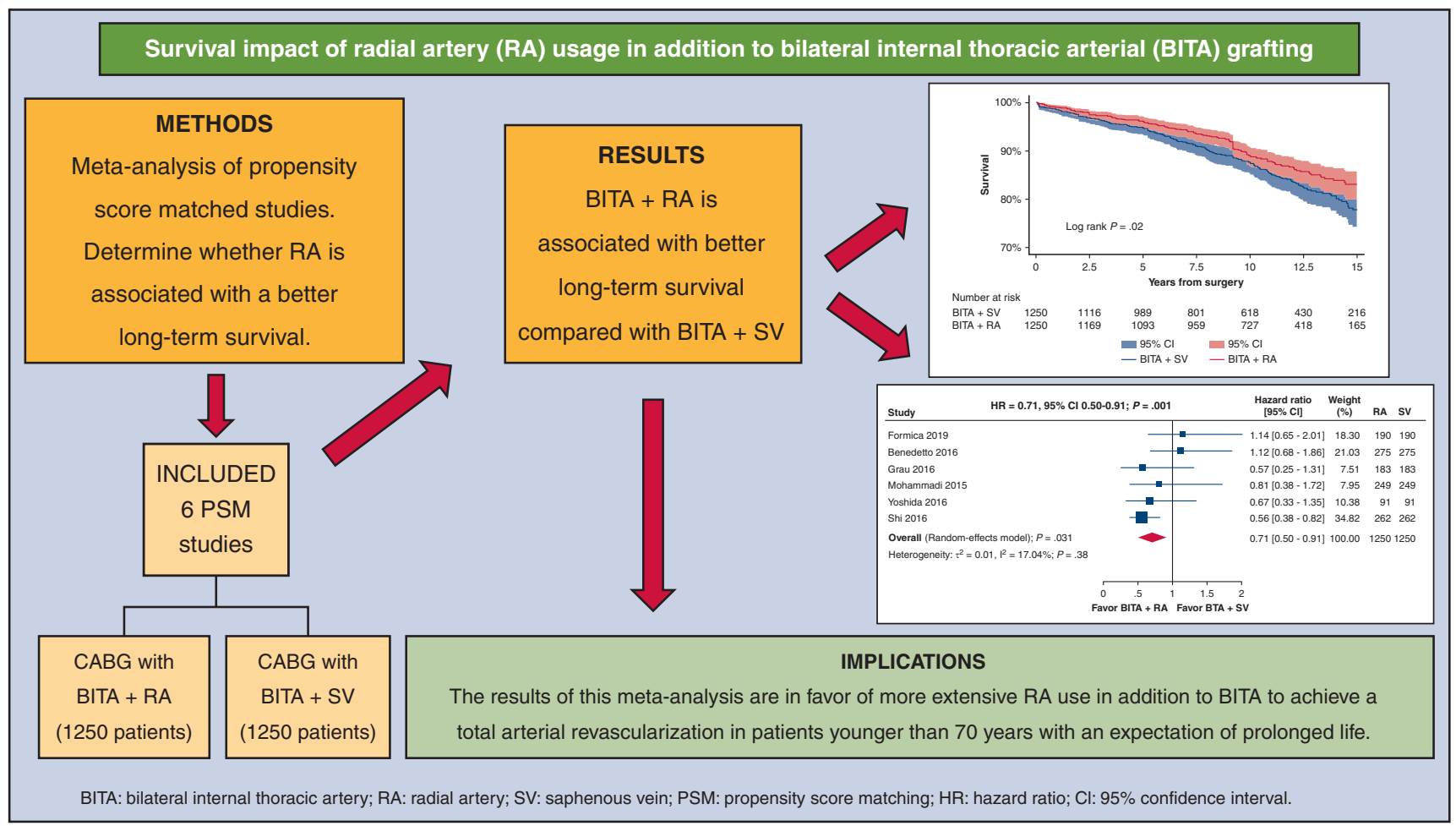

FIGURE 5. The figure shows the methods applied to realize this meta-analysis, the results, and the implication of our findings. Six propensity scorematched (PSM) studies were identified to determine whether use of the radial artery $(R A)$, in addition to the bilateral internal thoracic artery (BITA) is associated with a longer-term survival compared with the saphenous vein $(S V)$ in addition to the BITA (BITA + SV), in patients who underwent coronary artery bypass grafting $(C A B G)$. The pooled hazard ratio $(H R)$ was in favor of use of the BITA and RA (BITA + RA; HR, $0.71 ; 95 \%$ confidence interval $[C I], 0.50-$ $0.91 ; P=.03$ ) with a low heterogeneity: $I^{2}, 17.4 \% ; P=.38$. The pooled Kaplan-Meier survival analysis showed a longer survival in the BITA + RA group (log rank test $P=.02$ ). 


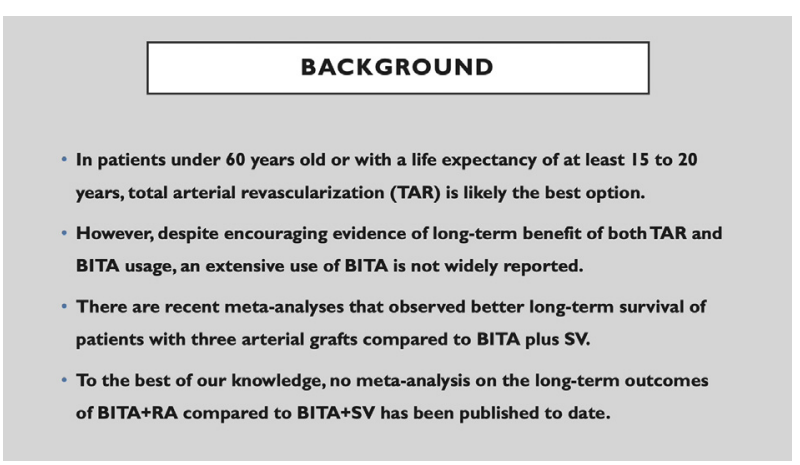

VIDEO 1. The video shows the introduction, methods, and main findings of the meta-analysis. Video available at: https://www.jtcvs.org/article/ S0022-5223(21)01033-3/fulltext.

$\mathrm{SV} ; \mathrm{n}=910)$ or SITA + RA with or without the SV $(\mathrm{n}=744)$ revealed a significant lower rate of graft RA occlusion compared with SV grafts (OR, 0.59; 95\% CI, 0.470.73 ), hence showing an advantageous usage of BITA and a superior graft patency of the RA. ${ }^{42}$ On the basis of our metaanalysis, the latest RAPCO report regarding the comparison between the RA and SV, and the study by Ruttmann and colleagues, ${ }^{42}$ we believe that it is reasonable to strongly consider TAR with BITA and RA in selected young patients with 3-vessel coronary artery disease.

This meta-analysis highlights the favorable advantage of BITA + RA over BITA + SV. There is recent evidence regarding the encouraging results of TAR with only BITA composite graft configuration ${ }^{43,44}$ and evidence regarding noninferiority or superior benefit of TAR with SITA + RA (composite T graft) compared with BITA or with SITA + SV, respectively. ${ }^{45,46}$ However, which TAR strategy ( 2 or 3 arteries) is best to recommend needs to be further investigated.

\section{Limitation}

This study is subject to the limitations of meta-analyses of observational studies that can suffer from a relevant risk of treatment allocation bias. The surgeon's decision to use either the RA or the SV as third conduit cannot be neutralized using any statistical method. Surgeons with extensive experience in using the RA are more likely to use this graft instead of the SV. Moreover, unmeasured or unknown confounders cannot be controlled using the PSM method, resulting in potential bias.

Only 6 PSM studies were included, which is perhaps a limitation of statistical significance and interpretation of meta-regression. For primary research, it is recommended to apply the rule of 10 subjects for each covariate to perform a robust linear regression, which would correspond to 10 studies for each moderator in meta-regression analysis. ${ }^{47}$

Additionally, the studies included in this analysis are limited by a relatively small number of patients, who share a very low operative risk. Although selection bias is inherent in each study, all studies had low rates of heterogeneity.

Finally, most patients included in this meta-analysis were younger than 70 years at the time of intervention with expectation of prolonged life. In such patients, whose 2 most predominant myocardial territories were grafted with 2 internal thoracic arteries, the superiority of the RA compared with the $\mathrm{SV}$ is demonstrable in long-term survival greater than 15 to 20 years, as already theorized by others. ${ }^{11,12}$ Further data, however, are still required.

\section{CONCLUSIONS}

In a meta-analysis of the PSM studies that compared BITA + RA versus BITA + SV, use of BITA + RA was not associated with increased operative risk, and appears to be associated with a significant survival benefit at longterm follow-up. This argues in favor of more extensive RA usage to achieve a total arterial myocardial revascularization in patients younger than 70 years with expectation of prolonged life.

\section{Conflict of Interest Statement}

The authors reported no conflicts of interest.

The Journal policy requires editors and reviewers to disclose conflicts of interest and to decline handling or reviewing manuscripts for which they may have a conflict of interest. The editors and reviewers of this article have no conflicts of interest.

The authors Lois Katharine Clegg, professor of Business English at University of Parma, for her tireless and high value contribution during the correction and writing of the article and Giorgia Pavan for her precious contribution to the English correction of the manuscript and to the video creation.

\section{References}

1. Sousa-Uva M, Neumann FJ, Ahlsson A, Alfonso F, Banning AP, Benedetto U, et al. 2018 ESC/EACTS guidelines on myocardial revascularization. Eur J Cardiothorac Surg. 2019;55:4-90.

2. Taggart DP, Benedetto U, Gerry S, Altman DG, Gray AM, Lees B, et al. Bilateral versus single internal-thoracic-artery grafts at 10 years. N Engl J Med. 2019;380: 437-46.

3. Weiss AJ, Zhao S, Tian DH, Taggart DP, Yan TD. A meta-analysis comparing bilateral internal mammary artery with left internal mammary artery for coronary artery bypass grafting. Ann Cardiothorac Surg. 2013;2:390-400.

4. Takagi H, Goto SN, Watanabe T, Mizuno Y, Kawai N, Umemoto T. A metaanalysis of adjusted hazard ratios from 20 observational studies of bilateral versus single internal thoracic artery coronary artery bypass grafting. J Thorac Cardiovasc Surg. 2014;148:1282-90.

5. Buttar SN, Yan TD, Taggart DP, Tian DH. Long-term and short-term outcomes of using bilateral internal mammary artery grafting versus left internal mammary artery grafting: a meta-analysis. Heart. 2017;103:1419-26.

6. Pevni D, Mohr R, Kramer A, Paz Y, Nesher N, Ben-Gal Y. Are two internal thoracic grafts better than one? An analysis of 5301 cases. Eur J Cardiothorac Surg. 2019;56:935-41.

7. Navia D, Espinoza J, Vrancic M, Piccinini F, Camporrotondo M, Dorsa A, et al. Bilateral internal thoracic artery grafting in elderly patients: any benefit in survival? J Thorac Cardiovasc Surg. October 3, 2020 [Epub ahead of print]. 
8. Locker C, Schaff HV, Daly RC, Dearani JA, Bell MR, Frye RL, et al. Multiple arterial grafts improve survival with coronary artery bypass graft surgery versus conventional coronary artery bypass grafting compared with percutaneous coronary interventions. J Thorac Cardiovasc Surg. 2016;152:369-79.e4.

9. Locker C, Schaff HV, Daly RC, Bell MR, Frye RL, Stulak JM, et al. Multiarterial grafts improve the rate of early major adverse cardiac and cerebrovascular events in patients undergoing coronary revascularization: analysis of 12 615 patients with multivessel disease. Eur J Cardiothorac Surg. 2017;52: 746-52.

10. Shi WY, Tatoulis J, Newcomb AE, Rosalion A, Fuller JA, Buxton BF. Is a third arterial conduit necessary? Comparison of the radial artery and saphenous vein in patients receiving bilateral internal thoracic arteries for triple vessel coronary disease. Eur J Cardiothorac Surg. 2016;50:53-60.

11. Mohammadi S, Dagenais F, Voisine P, Dumont E, Charbonneau E, Marzouk M, et al. Impact of the radial artery as an additional arterial conduit during in-situ bilateral internal mammary artery grafting: a propensity score-matched study. Ann Thorac Surg. 2016;101:913-8.

12. Benedetto U, Caputo M, Zakkar M, Bryan A, Angelini GD. Are three arteries better than two? Impact of using the radial artery in addition to bilateral internal thoracic artery grafting on long-term survival. J Thorac Cardiovasc Surg. 2016;152:862-9.e2.

13. Formica F, D'Alessandro S, Singh G, Ciobanu AM, Messina LA, Scianna S, et al. The impact of radial artery or the saphenous vein in addition to the bilateral internal mammary arteries on late survival: a propensity score analysis. $J$ Thorac Cardiovasc Surg. 2019;158:141-51.

14. Gaudino M, Puskas JD, Di Franco A, Ohmes LB, Iannaccone M, Barbero U, et al. Three arterial grafts improve late survival: a meta-analysis of propensitymatched studies. Circulation. 2017;135:1036-44.

15. Di Mauro M, Lorusso R, Di Franco A, Foschi M, Rahouma M, Soletti G, et al. What is the best graft to supplement the bilateral internal thoracic artery to the left coronary system? A meta-analysis. Eur J Cardiothorac Surg. 2019;56: 21-9.

16. Moher D, Liberati A, Tetzlaff J, Altman DG, PRISMA Group. Preferred reporting items for systematic reviews and meta-analyses: the PRISMA Statement. Open Med. 2009;3:e123-30.

17. Tierney JF, Stewart LA, Ghersi D, Burdett S, Sydes MR. Practical methods for incorporating summary time-to-event data into meta-analysis. Trials. 2007;8: 16.

18. Parmar MK, Torri V, Stewart L. Extracting summary statistics to perform metaanalyses of the published literature for survival endpoints. Stat Med. 1998;17: 2815-34.

19. Luo D, Wan X, Liu J, Tong T. Optimally estimating the sample mean from the sample size, median, mid-range, and/or mid-quartile range. Stat Methods Med Res. 2018;27:1785-805.

20. Higgins JP, Thompson SG. Quantifying heterogeneity in a meta-analysis. Stat Med. 2002;21:1539-58.

21. Egger M, Davey Smith G, Schneider M, Minder C. Bias in meta-analysis detected by a simple, graphical test. BMJ. 1997;315:629-34.

22. Begg CB, Mazumdar M. Operating characteristics of a rank correlation test for publication bias. Biometrics. 1994;50:1088-101.

23. Viechtbauer W, Cheung MW. Outlier and influence diagnostics for meta-analysis. Res Synth Methods. 2010;1:112-25.

24. Wei Y, Royston P. Reconstructing time-to-event data from published KaplanMeier curves. Stata J. 2017;17:786-802.

25. Grau JB, Kuschner CE, Johnson CK, Ferrari G, Zapolanski A, Brizzio ME, et al. The effects of using a radial artery in patients already receiving bilateral internal mammary arteries during coronary bypass grafting: 30-day outcomes and 14year survival in a propensity-matched cohort. Eur J Cardiothorac Surg. 2016; 49:203-10.

26. Yoshida S, Numata S, Tsutsumi Y, Monta O, Yamazaki S, Seo H, et al. Short- and long-term results of radial artery and saphenous vein grafts in the right coronary system: a propensity-matched study. Surg Today. 2017;47:335-43.

27. Zhang H, Wang ZW, Wu HB, Hu XP, Zhou Z, Xu P. Radial artery graft vs. saphenous vein graft for coronary artery bypass surgery: which conduit offers better efficacy? Herz. 2014;39:458-65.

28. Goldman S, Zadina K, Moritz T, Ovitt T, Sethi G, Copeland JG, et al. Long-term patency of saphenous vein and left internal mammary artery grafts after coronary artery bypass surgery: results from a Department of Veterans Affairs cooperative study. J Am Coll Cardiol. 2004;44:2149-56.
29. Buxton BF, Shi WY, Tatoulis J, Fuller JA, Rosalion A, Hayward FA. Total arterial revascularization with internal thoracic and radial artery grafts in triple-vessel coronary artery disease is associated with improved survival. $J$ Thorac Cardiovasc Surg. 2014;148:1238-44.

30. Buxton BF, Hayward PA, Raman J, Moten SC, Rosalion A, Gordon I, et al. Longterm results of the RAPCO trials. Circulation. 2020;142:1330-8.

31. Bisleri G, Di Bacco L, Turturiello D, Mazzoletti A, Giroletti L, Repossini A, et al. Improved outcomes of total arterial myocardial revascularization in elderly patients at long-term follow-up: a propensity-matched analysis. Ann Thorac Surg. 2017;103:517-25.

32. Urso S, Sadaba R, Gonzàlez JM, Nogales E, Pettinari M, Tena MA, et al. Total arterial revascularization strategies: a meta-analysis of propensity scorematched observational studies. J Card Surg. 2019;34:837-45.

33. Di Mauro M, Contini M, Iacò AL, Bivona A, Gagliardi M, Varone E, et al. Bilateral internal thoracic artery on the left side: a propensity score matched study of impact of the third conduit on the right side. J Thorac Cardiovasc Surg. 2009; 137:869-74.

34. Gaudino M, Benedetto U, Fremes S, Biondi-Zoccai G, Sedrakyan A, Puskas JD, et al. Radial-artery or saphenous-vein grafts in coronary-artery bypass surgery. $N$ Engl J Med. 2018;378:2069-77.

35. Buxton BF, Raman JS, Ruengsakulrach P, Gordon I, Rosalion A, Bellomo R, et al. Radial artery patency and clinical outcomes: five-year interim results of a randomized trial. J Thorac Cardiovasc Surg. 2003;125:1363-71.

36. Mastrobuoni S, Gawad N, Price J, Chan V, Ruel M, Mesana TG, et al. Use of bilateral internal thoracic artery during coronary artery bypass graft surgery in Canada: the Bilateral Internal Thoracic Artery Survey. J Thorac Cardiovasc Surg. 2012;144:874-9.

37. Schwann TA, El Hage Sleiman AK, Yammine MB, Tranbaugh RF, Engoren M, Bonnell MR, et al. The incremental value of three or more arterial grafts in CABG: the effect of native vessel disease. Ann Thorac Surg. 2018;106:1071-8.

38. Iribarne A, Goodney PP, Flores AM, DeSimone J, Di Scipio AW, Austin A, et al. National trends and geographic variation in bilateral internal mammary artery use in the United States. Ann Thorac Surg. 2017;104:1902-7.

39. Kappetein AP, Dawkins KD, Mohr FW, Morice MC, Mack MJ, Russell ME, et al. Current percutaneous coronary intervention and coronary artery bypass grafting practices for three-vessel and left main coronary artery disease. Insights from the SYNTAX run-in phase. Eur J Cardiothorac Surg. 2006;29:486-91.

40. Gaudino M, Bakaeen FG, Benedetto U, Di Franco A, Fremes S, Glineur D, et al. Arterial grafts for coronary bypass: a critical review after the publication of ART and RADIAL. Circulation. 2019;140:1273-84

41. Velez AK, Canner JK, Etchill E, Giuliano K, Alejo DE, Choi C, et al. Measures to increase use of multiple arterial grafts for isolated coronary artery bypass grafting. J Am Coll Surg. 2021;232:954-61.

42. Ruttmann E, Dietl M, Feuchtner GM, Metzler B, Bonaros N, Taggart DP, et al. Long-term clinical outcome and graft patency of radial artery and saphenous vein grafts in multiple arterial revascularization. J Thorac Cardiovasc Surg. 2019;158:442-50.

43. Glineur D, Boodhwani M, Hanet C, de Kerchove L, Navarra E, Astarci P, et al. Bilateral internal thoracic artery configuration for coronary artery bypass surgery: a prospective randomized trial. Circ Cardiovasc Interv. 2016;9:e003518.

44. Navia DO, Vrancic M, Piccinini F, Camporrotondo M, Dorsa A, Espinoza J, et al. Myocardial revascularization exclusively with bilateral internal thoracic arteries in T-graft configuration: effects on late survival. Ann Thorac Surg. 2016;101: 1775-81.

45. Pevni D, Mohr R, Paz Y, Kramer A, Ben-Gal Y, Nesher N, et al. Long-term outcome of revascularization with composite T-grafts: is bilateral internal mammary grafting better than single mammary and radial artery grafting? J Thorac Cardiovasc Surg. 2016;151:1311-9.

46. Obed D, Fleissner F, Martens A, Cebotari S, Heverich A, Warnecke G, et al. Total arterial revascularization with radial artery and internal thoracic artery T-grafts is associated with superior long-term survival in patients undergoing coronary artery bypass grafting. Ann Thorac Cardiovasc Surg. 2020;26:30-9.

47. Peduzzi P, Concato J, Kemper E, Holford TR, Feinstein AR. A simulation study of the number of events per variable in logistic regression analysis. J Clin Epidemiol. 1996;49:1373.e9.

Key Words: total arterial revascularization, internal thoracic arteries, radial artery, saphenous vein graft, $\mathrm{CABG}$ 


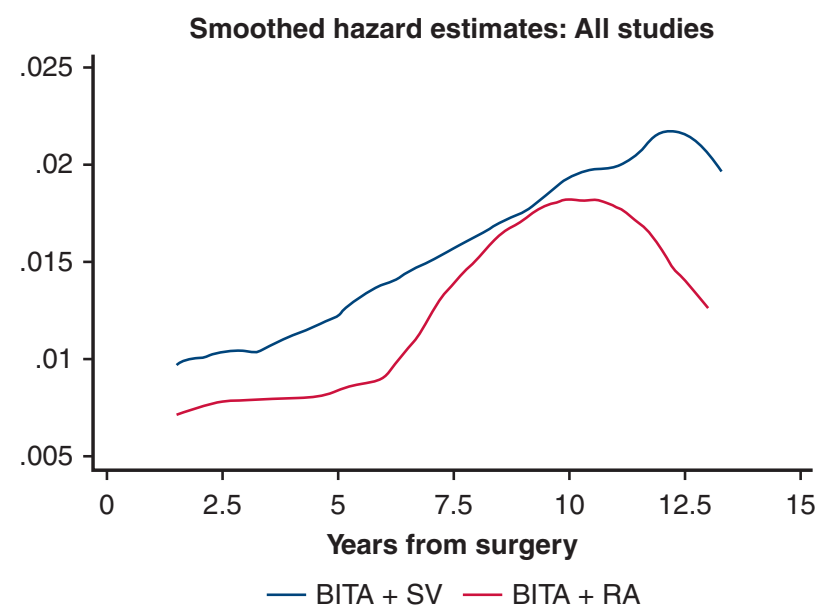

FIGURE E1. Smoothed hazard function of all of the databases pooled in 1 global database. BITA $+S V$, Bilateral internal thoracic artery and saphenous vein; $B I T A+R A$, bilateral internal thoracic artery and radial artery.

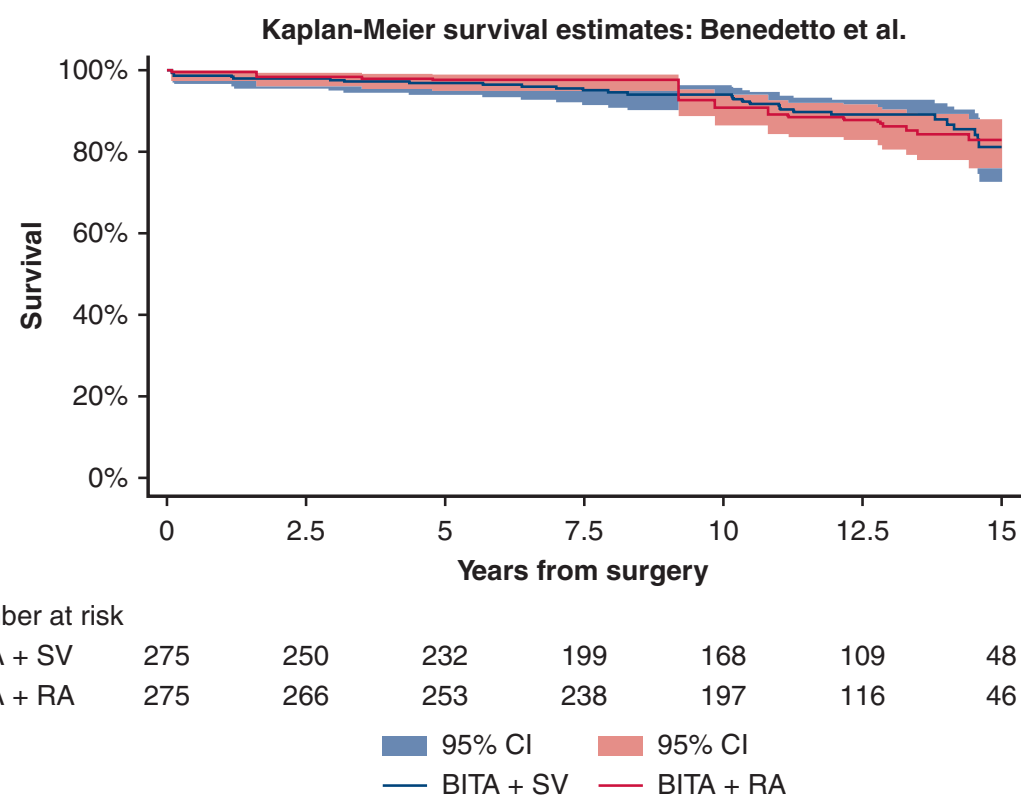

FIGURE E2. Reconstructed Kaplan-Meier survival curves of Benedetto et al. ${ }^{12} B I T A+S V$, Bilateral internal thoracic artery and saphenous vein; $B I T A+R A$, bilateral internal thoracic artery and radial artery; $C I$, confidence interval. 


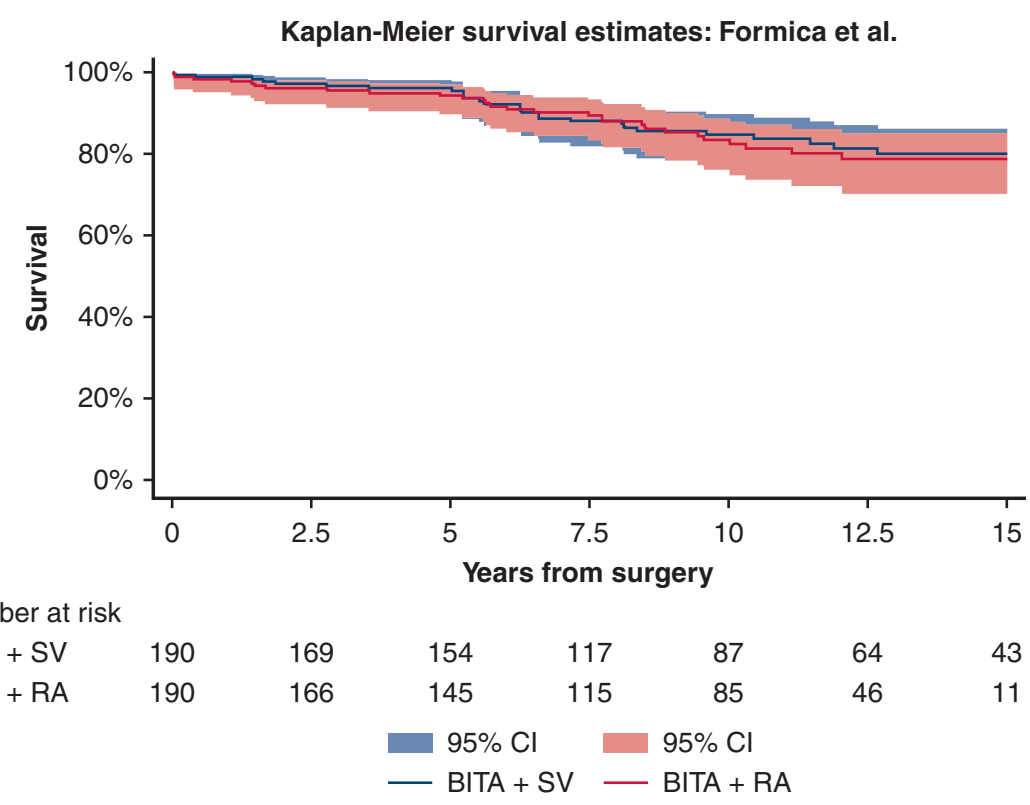

FIGURE E3. Reconstructed Kaplan-Meier survival curves of Formica et al. ${ }^{13} B I T A+S V$, Bilateral internal thoracic artery and saphenous vein; $B I T A+R A$, bilateral internal thoracic artery and radial artery; $C I$, confidence interval.

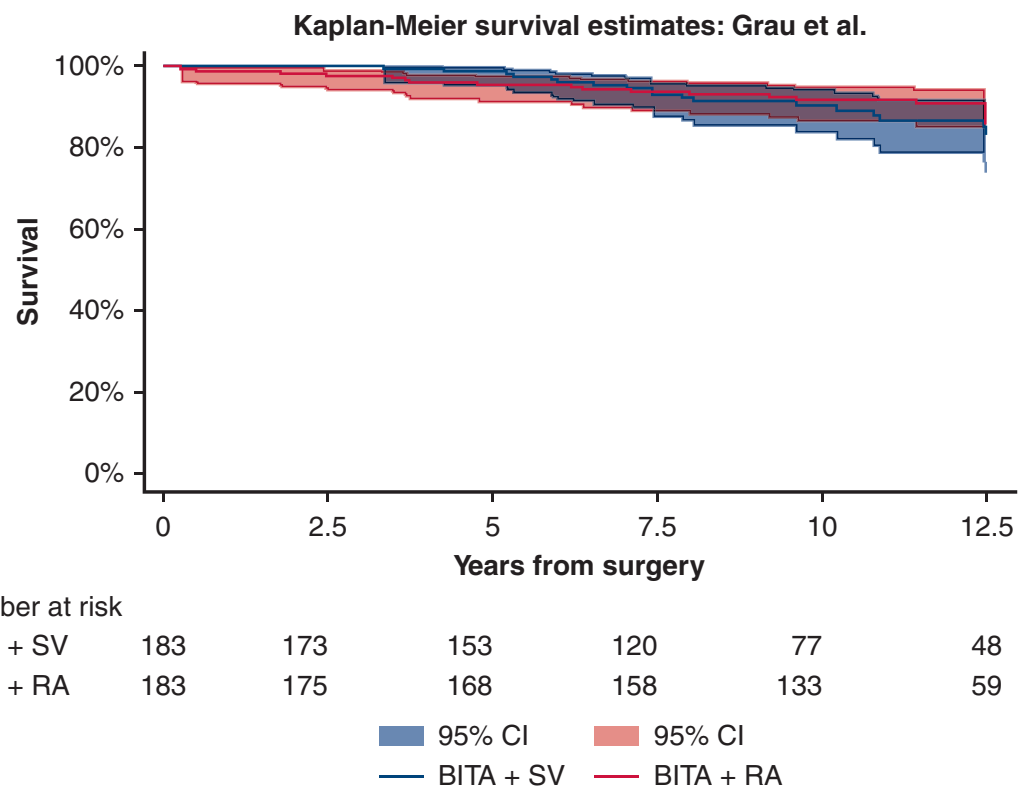

FIGURE E4. Reconstructed Kaplan-Meier survival curves of Grau et al. ${ }^{25} B I T A+S V$, Bilateral internal thoracic artery and saphenous vein; $B I T A+R A$, bilateral internal thoracic artery and radial artery; $C I$, confidence interval. 


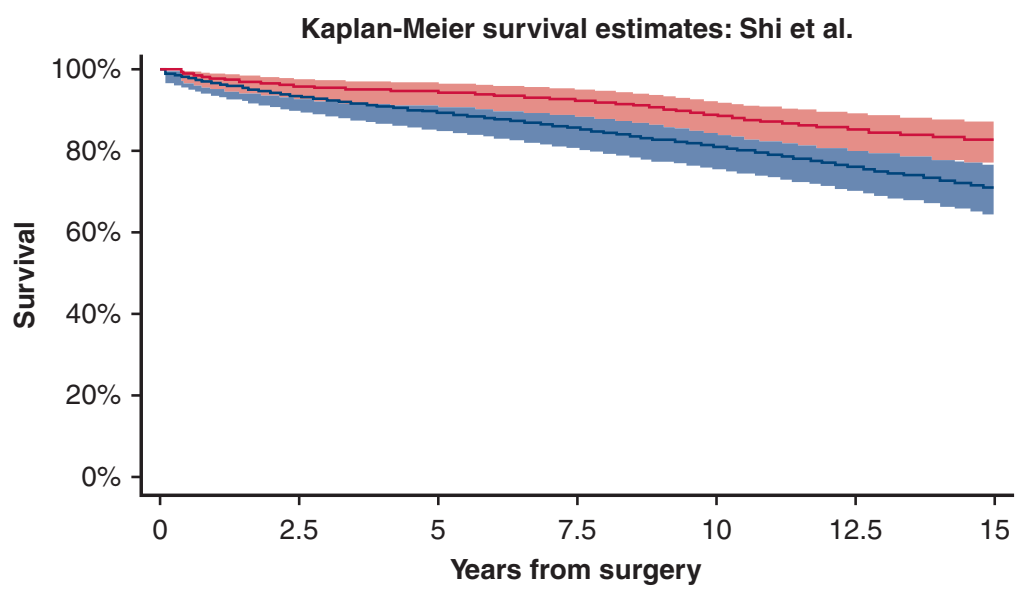

Number at risk

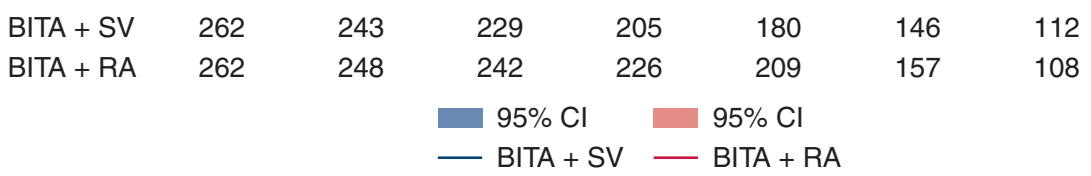

FIGURE E5. Reconstructed Kaplan-Meier survival curves of Shi et al ${ }^{10} B I T A+S V$, Bilateral internal thoracic artery and saphenous vein; BITA $+R A$, bilateral internal thoracic artery and radial artery; $C I$, confidence interval.

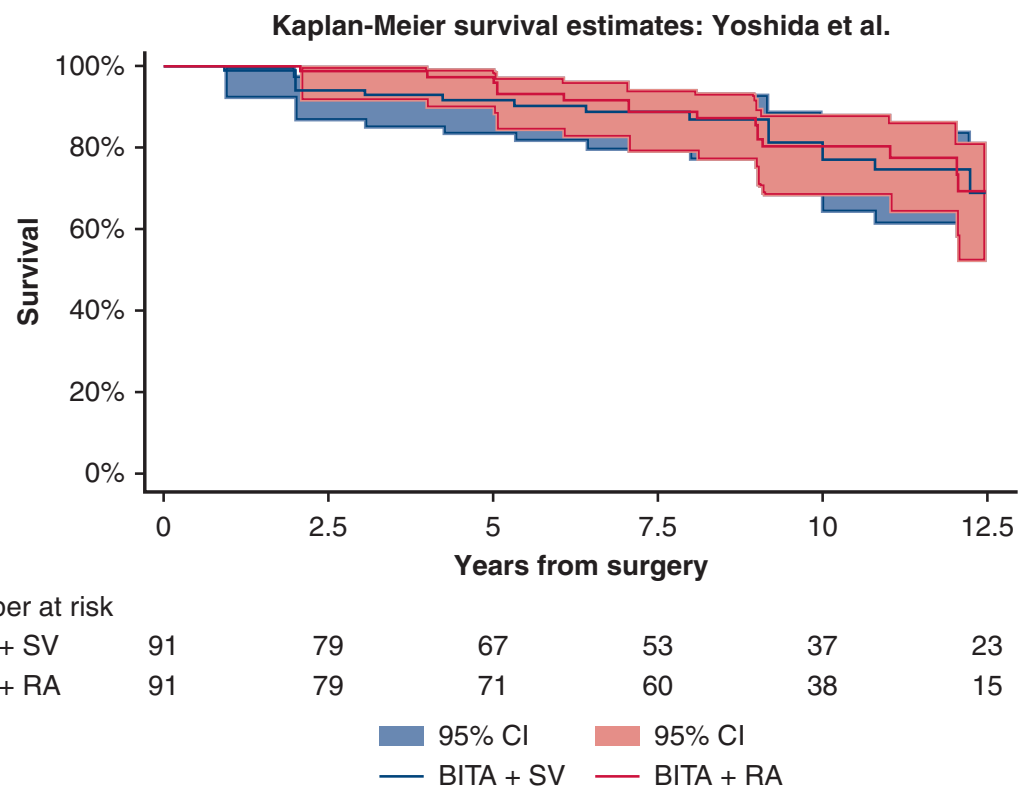

FIGURE E6. Reconstructed Kaplan-Meier survival curves of Yoshida et al. ${ }^{26} B I T A+S V$, Bilateral internal thoracic artery and saphenous vein; $B I T A+R A$, bilateral internal thoracic artery and radial artery; $C I$, confidence interval. 


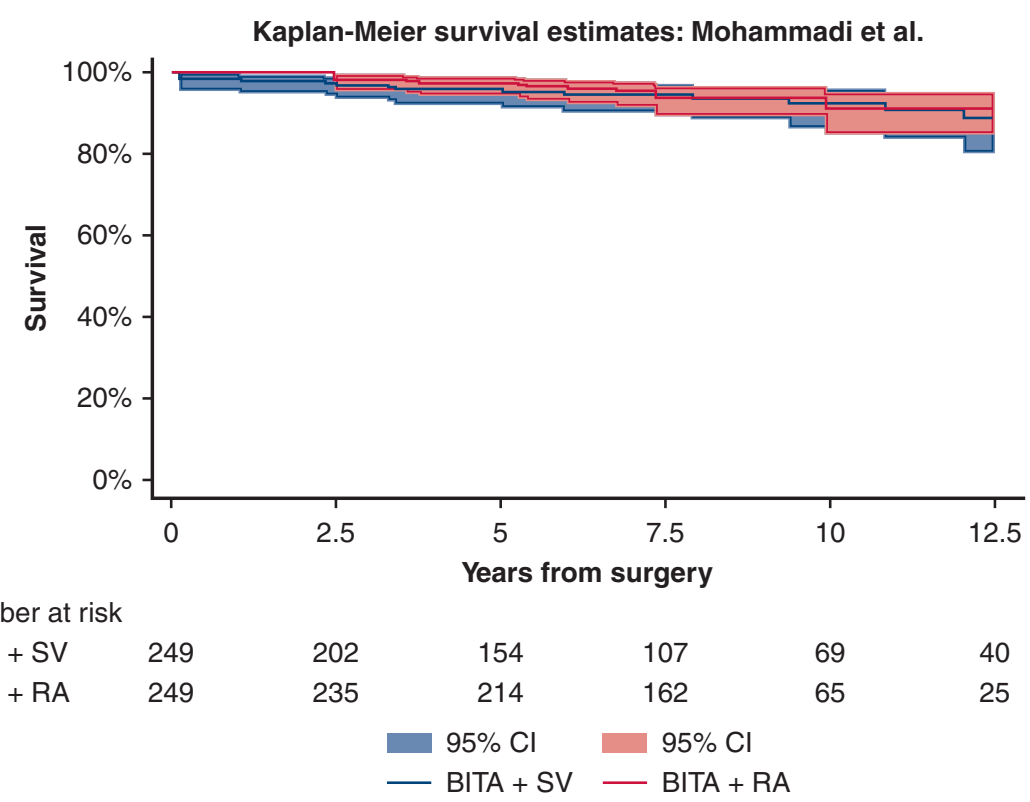

FIGURE E7. Reconstructed Kaplan-Meier survival curves of Mohammadi et al. ${ }^{11} B I T A+S V$, Bilateral internal thoracic artery and saphenous vein; $B I T A+R A$, bilateral internal thoracic artery and radial artery; $C I$, confidence interval.

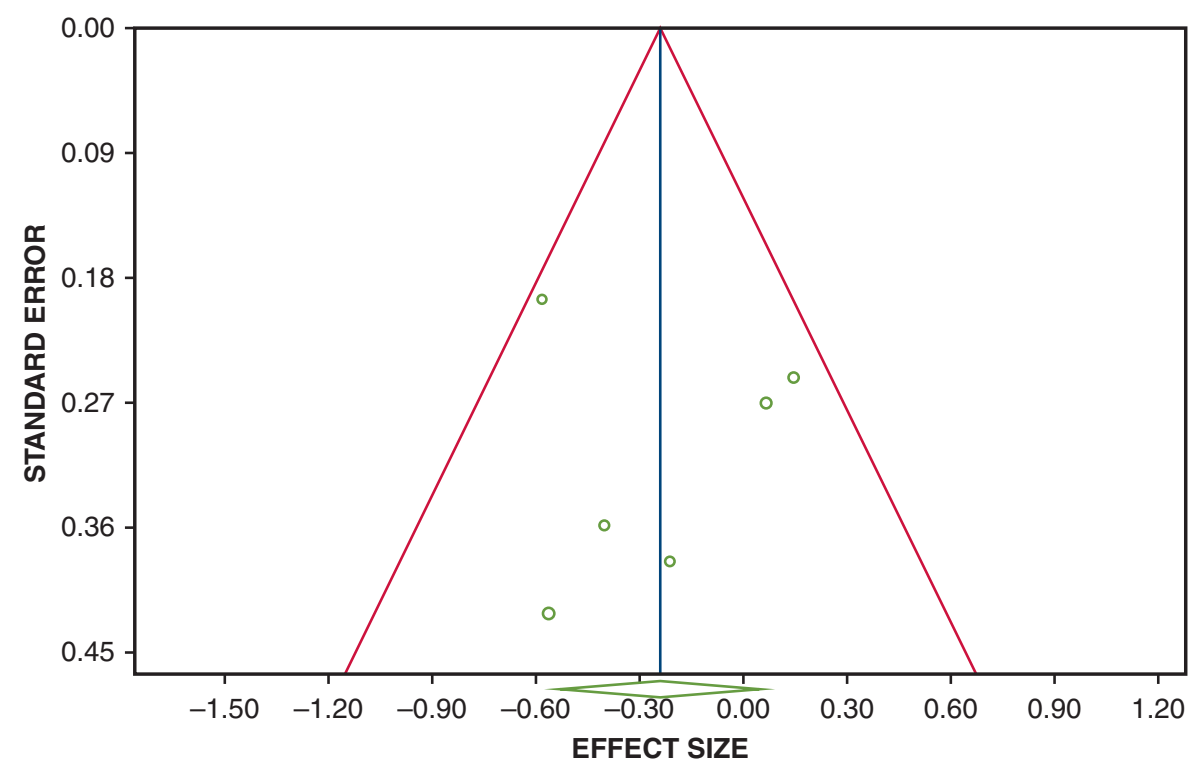

FIGURE E8. Funnel plot to assess publication bias. No publication bias was revealed related to long-term survival. 


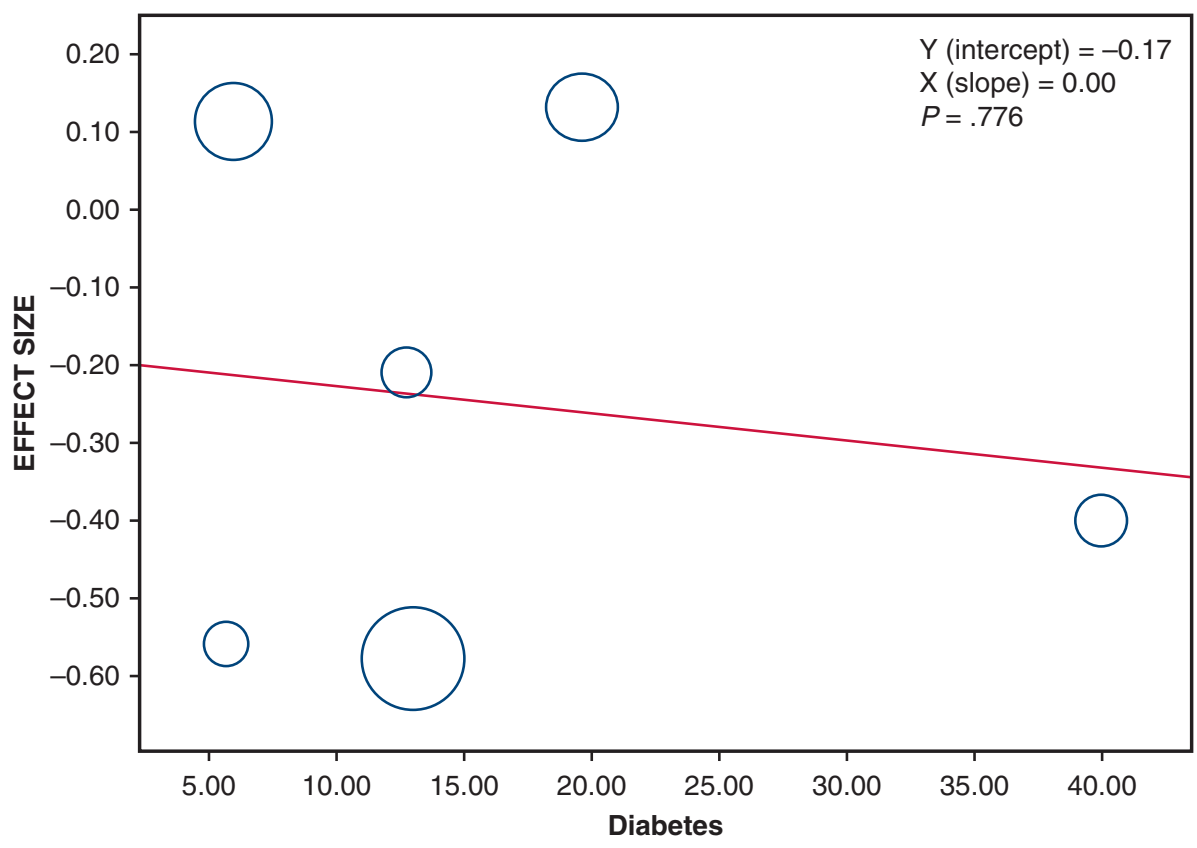

FIGURE E9. Meta-regression analysis plot: effect of diabetes. No effect of diabetes on long-term survival was reported $(P=.776 ; \beta$ regression coefficient, $-0.00)$.

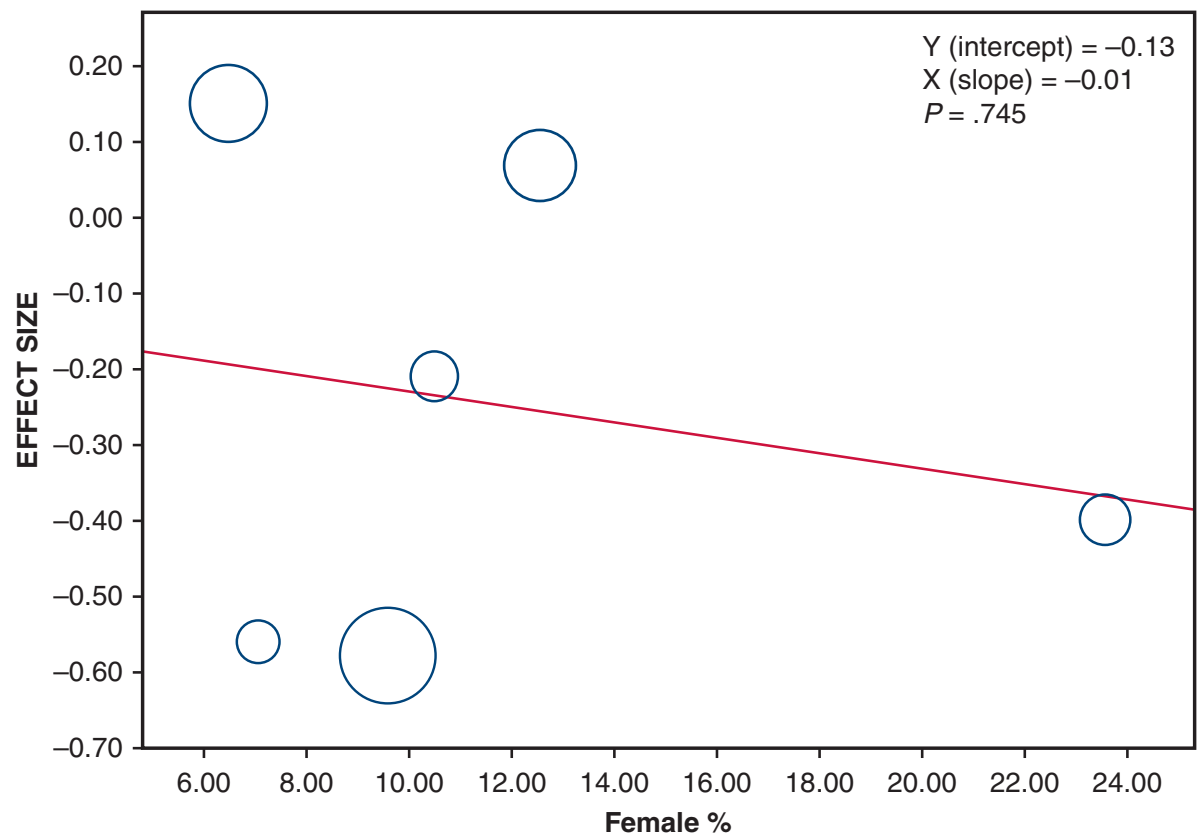

FIGURE E10. Meta-regression analysis plot: effect of female sex. No effect of female sex on long-term survival was reported $(P=.745 ; \beta$ regression coefficient, -0.01 ). 


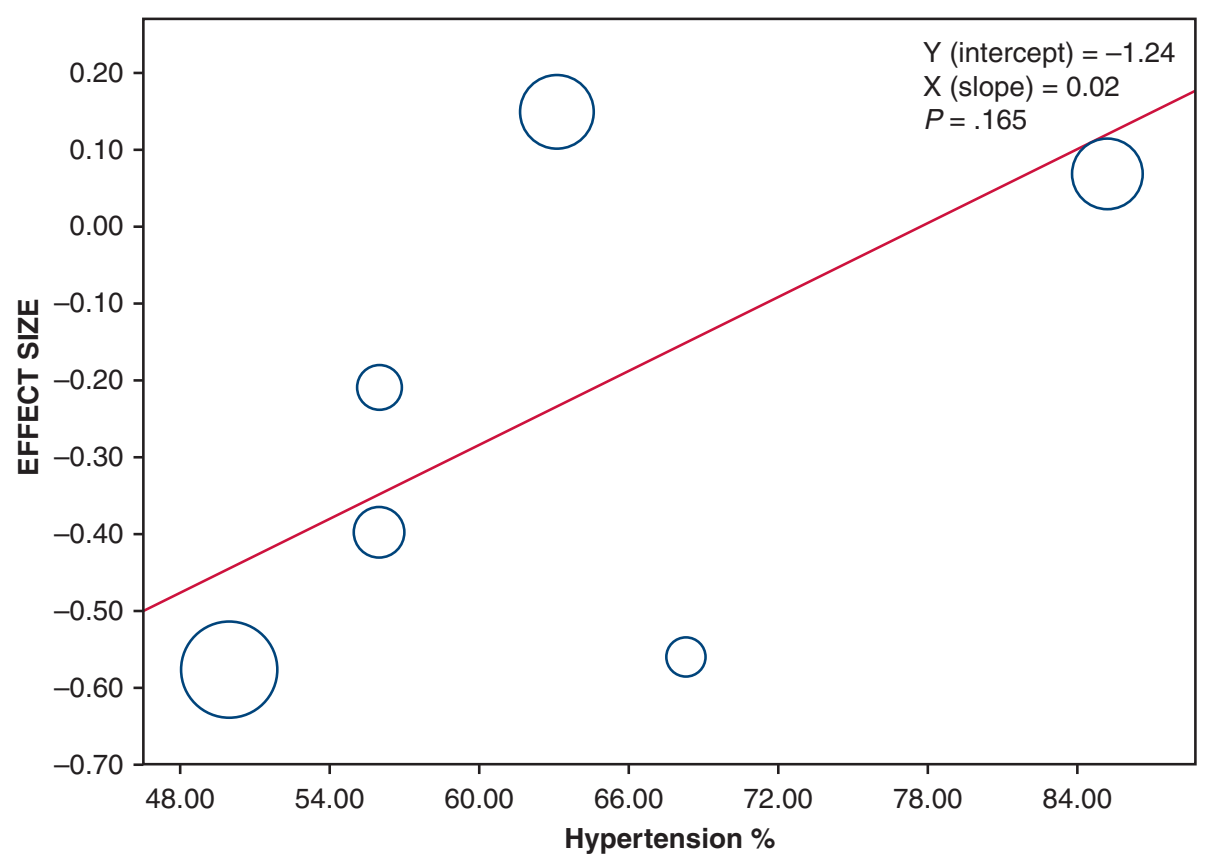

FIGURE E11. Meta-regression analysis plot: effect of hypertension. No effect of hypertension on long-term survival was reported $(P=.165 ; \beta$ regression coefficient, 0.02).

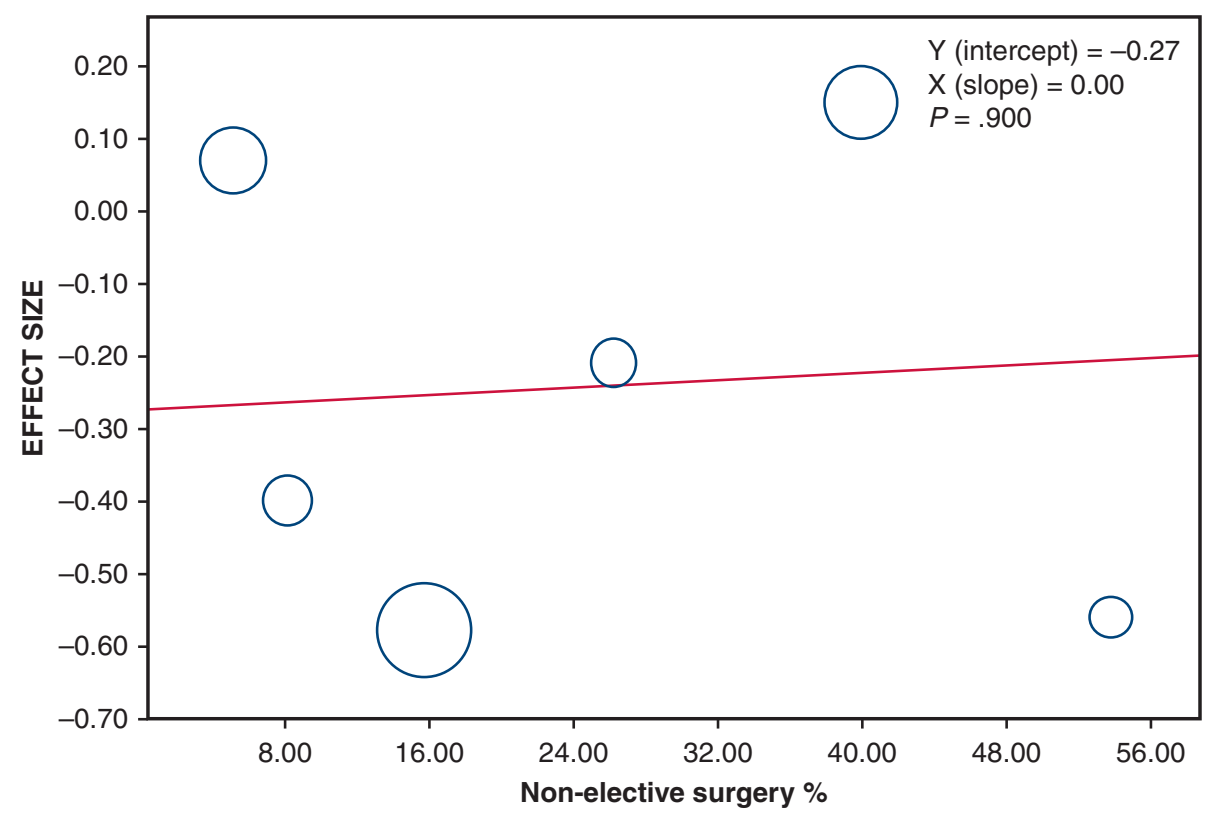

FIGURE E12. Meta-regression analysis plot: effect of nonelective surgery. No effect of nonelective surgery on long-term survival was reported $(P=.900$; $\beta$ regression coefficient, 0.00 ). 


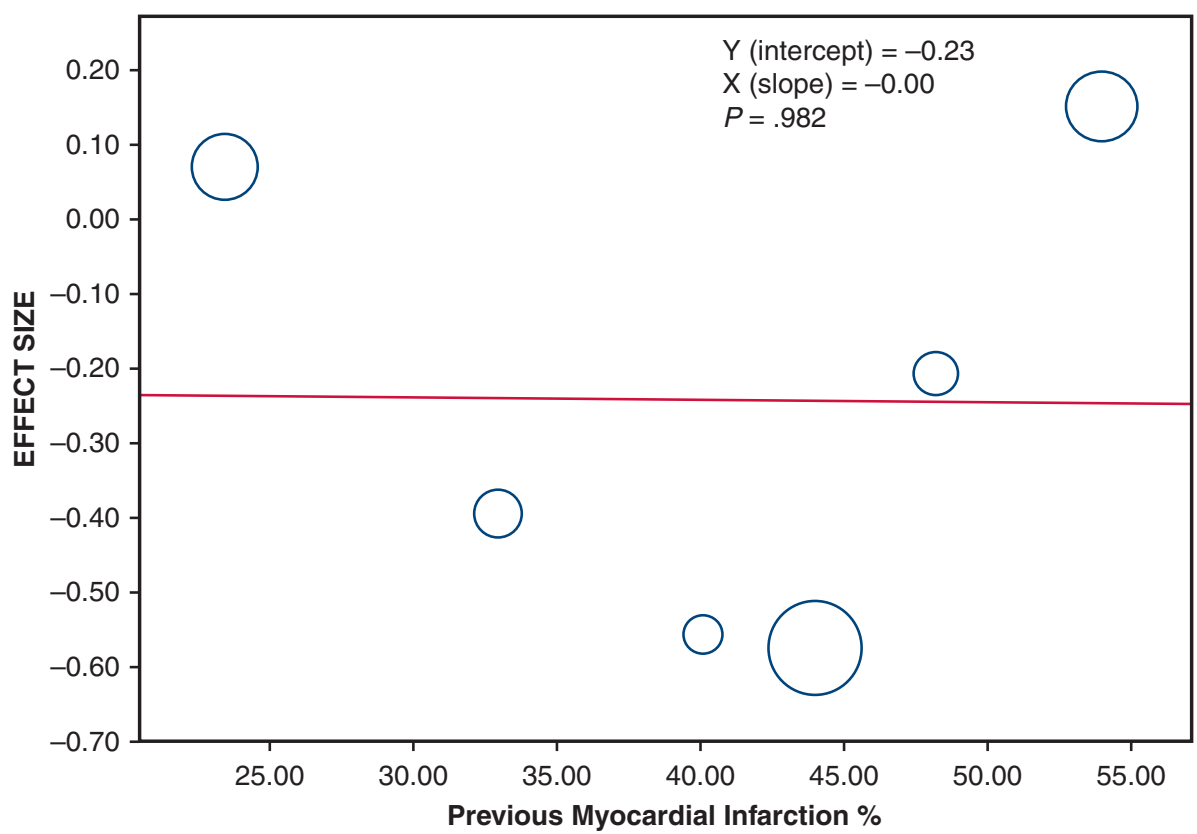

FIGURE E13. Meta-regression analysis plot: effect of previous myocardial infarction. No effect of previous myocardial infarction on long-term survival was reported $(P=.982 ; \beta$ regression coefficient, 0.00$)$. 
TABLE E1. Bilateral internal thoracic artery graft configuration, coronary target of the radial artery and saphenous vein grafts and stenosis, and stenosis degree of radial artery coronary target

\begin{tabular}{|c|c|c|c|c|c|}
\hline Authors & $\begin{array}{l}\text { BITA + RA; } \\
\text { RA target }\end{array}$ & $\begin{array}{l}\text { BITA + SV; } \\
\text { SV target }\end{array}$ & $\begin{array}{c}\text { BITA + RA; BITA } \\
\text { configuration }\end{array}$ & $\begin{array}{c}\text { BITA }+ \text { SV; } \\
\text { BITA configuration }\end{array}$ & $\begin{array}{l}\text { RA graft; target } \\
\text { vessel stenosis }\end{array}$ \\
\hline $\begin{array}{l}\text { Shi et al }^{10} \\
\text { Australia } \\
\text { Study period } \\
1977-2010\end{array}$ & $\begin{array}{l}\text { RCA: } 148(56.5 \%) \\
\text { CX system: N/A }\end{array}$ & $\begin{array}{l}\text { RCA: } 148(56.5 \%) \\
\text { CX system: N/A }\end{array}$ & $\begin{array}{l}\text { RITA to RCA: } 94 \\
(36 \%) \\
\text { BITA in situ to LCA } \\
\text { system: } 65(25 \%) \\
\text { Free RITA: } 175(67 \%)\end{array}$ & $\begin{array}{l}\text { RITA to RCA: } 89 \\
\quad(34 \%) \\
\text { BITA in situ to LCA } \\
\text { system: } 67(26 \%) \\
\text { Free RITA: } 175(67 \%)\end{array}$ & $\begin{array}{l}\text { CX }>80 \%: 168 \\
\quad(64 \%) \\
\text { RCA: } 202(77 \%)\end{array}$ \\
\hline $\begin{array}{l}\text { Mohammadi et al }{ }^{11} \\
\text { Canada } \\
\text { Study period } \\
1991-2013\end{array}$ & $\begin{array}{l}\text { CX: } 178(71.5 \%) \\
\text { RCA: } 54(21.7 \%) \\
\text { DA: } 17(6.8 \%)\end{array}$ & - & $\begin{array}{l}\text { LITA to LAD: } 230 \\
\quad(92.3 \%) \\
\text { LITA to CX: } 16 \\
\quad(6.4 \%) \\
\text { LITA to DA: } 3(1.2 \%) \\
\text { RITA to LAD: } 19 \\
\text { (7.6\%) } \\
\text { RITA to CX: } 48 \\
\quad(19.3 \%) \\
\text { RITA to RCA: } 182 \\
\text { ( } 73 \%) \\
\text { Free RITA: } 0\end{array}$ & $\begin{array}{l}\text { LITA to LAD: } 229 \\
\quad(91.9 \%) \\
\text { LITA to CX: } 18 \\
\text { ( } 7.2 \%) \\
\text { LITA to DA: } 2(0.8 \%) \\
\text { RITA to LAD: } 20 \\
\quad(8 \%) \\
\text { RITA to CX: } 87 \\
\quad(34.9 \%) \\
\text { RITA to RCA: } 142 \\
\text { (57\%) } \\
\text { Free RITA: } 0\end{array}$ & $\begin{array}{l}>90 \%: 69 \\
<90 \%: 180\end{array}$ \\
\hline $\begin{array}{l}\text { Benedetto et al } \\
\text { UK } \\
\text { Study period } \\
1996-2015\end{array}$ & $\begin{array}{l}\text { CX: } 150(54 \%) \\
\text { RCA: } 125(45 \%)\end{array}$ & $\begin{array}{l}\text { CX: } 117(43 \%) \\
\text { RCA: } 129(47 \%) \\
\text { CX + RCA: } 26(9 \%)\end{array}$ & $\begin{array}{l}\text { LITA to LAD: } 199 \\
\text { ( } 72 \%) \\
\text { LITA to CX: } 76 \\
\text { ( } 28 \%) \\
\text { RITA to LAD: } 70 \\
\text { ( } 25 \%) \\
\text { RITA to CX: } 92 \\
\text { ( } 34 \%) \\
\text { RITA to RCA: } 113 \\
\text { ( } 41 \%) \\
\text { Free RITA: } 53(19 \%)\end{array}$ & $\begin{array}{l}\text { LITA to LAD: } 203 \\
\text { ( } 74 \%) \\
\text { LITA to CX: } 72 \\
\text { ( } 26 \%) \\
\text { RITA to LAD: } 64 \\
\text { ( } 23 \%) \\
\text { RITA to CX: } 95 \\
\text { ( } 35 \%) \\
\text { RITA to RCA: } 367 \\
\text { ( } 24 \%) \\
\text { Free RITA: } 48(17 \%)\end{array}$ & $>75 \%$ \\
\hline $\begin{array}{l}\text { Formica et } \mathrm{al}^{13} \\
\text { Italy } \\
\text { Study period } \\
1999-2017\end{array}$ & $\begin{array}{l}\text { CX: } 30(15.8 \%) \\
\text { RCA: } 160(84.2 \%)\end{array}$ & $\begin{array}{l}\text { CX: } 7(3.6 \%) \\
\text { RCA: } 183(93.7 \%)\end{array}$ & $\begin{array}{l}\text { LITA to LAD: } 190 \\
\quad(100 \%) \\
\text { RITA to LAD: } 0 \\
\text { RITA to CX: } 30 \\
\quad(15.8 \%) \\
\text { RITA to RCA: } 160 \\
\quad(84.2 \%) \\
\text { BITA composite } \\
\text { Y-graft: } 21(11 \%)\end{array}$ & $\begin{array}{l}\text { LITA to LAD: } 183 \\
\text { (96.3\%) } \\
\text { RITA to LAD: } 7 \\
\text { (3.7\%) } \\
\text { RITA to CX: } 176 \\
\text { (92.6\%) } \\
\text { RITA to RCA: } 7 \\
\text { (3.7\%) } \\
\text { BITA composite } \\
\text { Y-graft: } 26(13.7 \%)\end{array}$ & $\begin{array}{l}\mathrm{RCA} \geq 90 \% \\
\mathrm{CX} \geq 75 \%\end{array}$ \\
\hline $\begin{array}{l}\text { Grau et } \mathrm{al}^{25} \\
\text { US } \\
\text { Study period } \\
2000-2013\end{array}$ & $\begin{array}{l}\text { N/A for matched } \\
\text { population }\end{array}$ & $\begin{array}{l}\text { N/A for matched } \\
\text { population }\end{array}$ & $\begin{array}{l}\text { N/A for matched } \\
\text { population }\end{array}$ & $\begin{array}{l}\text { N/A for matched } \\
\text { population }\end{array}$ & $\begin{array}{c}\text { Mean stenosis } \\
83.78 \%\end{array}$ \\
\hline $\begin{array}{l}\text { Yoshida et }^{26}{ }^{26} \\
\text { Japan } \\
\text { Study period } \\
\text { 1997-2007 }\end{array}$ & $\begin{array}{l}\text { N/A for matched } \\
\text { population }\end{array}$ & $\begin{array}{l}\text { N/A for matched } \\
\text { population }\end{array}$ & $\begin{array}{l}\text { N/A for matched } \\
\text { population }\end{array}$ & $\begin{array}{l}\text { N/A for matched } \\
\text { population }\end{array}$ & N/A \\
\hline
\end{tabular}


TABLE E2. The Newcastle-Ottawa quality assessment scale for the 6 propensity score-matched studies included in the analysis

\begin{tabular}{lcccc}
\hline \multicolumn{1}{c}{ Authors } & Score & Selection & Comparability & Outcome/exposure \\
\hline Shi et al & 10 & $* * * *$ & $* *$ & $* * *$ \\
Mohammadi et al $^{11}$ & 9 & $* * * *$ & $* *$ & $* * *$ \\
Benedetto et al $^{12}$ & 9 & $* * * *$ & $* *$ & $* *$ \\
Formica et al $^{13}$ & 9 & $* * * *$ & $* *$ & $* * *$ \\
${\text { Grau et } \mathrm{al}^{25}}^{\text {Yoshida et al }}{ }^{26}$ & 9 & $* * * *$ & $* *$ & $* * *$ \\
\hline
\end{tabular}

